\title{
Nove najdbe iz starejše železne dobe iz Zagorja ob Savi in Save pri Litiji
}

\author{
New Early Iron Age finds from \\ Zagorje ob Savi and Sava near Litija (Slovenia)
}

\author{
Miha MURKO, Matej DRAKSLER
}

\section{Izvleček}

Arheološki strokovni javnosti je Zagorje ob Savi znano že več kot stoletje, odkar so konec 19. stoletja naključno odkrili grobove iz starejše železne dobe. Leta 2011 so tod potekala zaščitna arheološka izkopavanja, ki so doprinesla k poznavanju najdišča in pokazala na njegov pomen. Odkritih je bilo 9 skeletnih grobov, od katerih sta bila dva otroška, dva ženska in pet moških. Izstopata grob z bronasto pasno garnituro ter grob z dobro ohranjenim ženskim okostjem in pridanimi jantarnimi jagodami, bronastim lasnim obročkom, kačasto fibulo ter lončkom. Odkrite so bile še druge najdbe, ki kažejo, da je na istem prostoru v pozni bronasti oziroma zgodnji železni dobi obstajala naselbina.

Najdbi fibule in sulice, odkriti nad Savo pri Litiji, dodatno osvetljujeta fenomen planega skeletnega pokopa, ki se je ob koncu halštatskega obdobja uveljavil v Zasavju.

Ključne besede: Zagorje ob Savi; Sava pri Litiji; starejša železna doba; dolenjska halštatska kulturna skupina; grobovi; naselbinske najdbe

\section{Abstract}

Zagorje ob Savi has been known as an archaeological site for more than a century, ever since burials from the Early Iron Age were unearthed there by chance towards the end of the $19^{\text {th }}$ century. The rescue archaeological investigations conducted in 2011 brought new evidence on the site and its significance. Nine inhumation burials were excavated, two of which belonged to children, two to women and five to men. Two of the burials stand out in their goods, one containing a bronze belt set and the other, with a well-preserved female skeleton, containing amber beads, a bronze hair ring, serpentine fibula and beaker. Other finds from the site indicate that a settlement stood here before the cemetery and was inhabited in the Late Bronze and/or beginning of the Early Iron Age.

At Sava near Litija (west of Zagorje ob Savi), the finds of a fibula and spearhead further advance our knowledge of the practice of flat inhumation burial that became the norm towards the end of the Hallstatt period in the Zasavje region.

Keywords: Slovenia; Zagorje ob Savi; Sava near Litija; Early Iron Age; Dolenjska Hallstatt cultural group; burials; settlement finds 


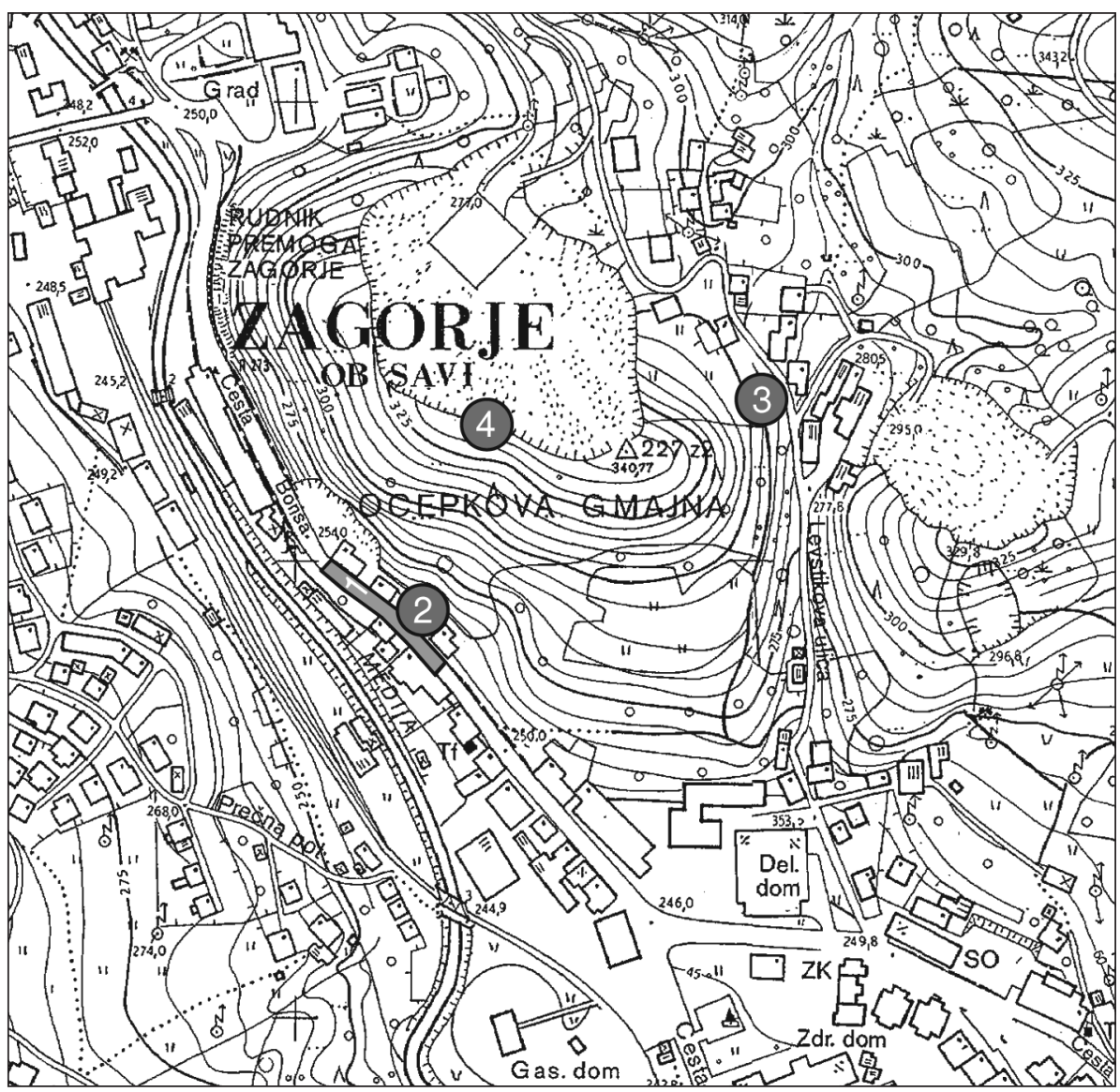

Sl. 1: Arheološka najdišča na območju Zagorja ob Savi. 1 - Cesta Borisa Kidriča (grobišče iz starejše železne dobe); 2 Milavčeva hiša (grobišče iz starejše železne dobe ); 3 - Levstikova ulica (grobišče iz mlajše železne dobe); 4 - Ocepkov hrib (domnevna prazgodovinska naselbina).

Fig. 1: Archaeological sites in Zagorje ob Savi. 1 - Cesta Borisa Kidriča (Early Iron Age cemetery); 2 - Milavčeva hiša (Early Iron Age cemetery); 3 - Levstikova ulica (Late Iron Age cemetery); 4 - Ocepkov hrib (supposed prehistoric settlement). (Vir / Source: (c) GURS, TTN5, 2004 - Litija 20, Trbovlje 11)

\section{ZAGORJE OB SAVI}

Območje Zagorja ob Savi je reliefno zelo razgibano. To je hribovit, težko prehoden svet podolžnih slemen in globoko zarezanih dolin. Po zagorskem podolju teče potok Medija, ki ima štiri večje in več manjših, predvsem hudourniških pritokov in se na jugu skozi tesen prebija do Save. Skozi ta preboj je omogočen prehod od savske rečne poti (sedaj jo spremljata železnica in cesta) ob Mediji in pritoku Orehovica do trojanskega prelaza oziroma ob pritoku Kandrščica do Kandrš. Od tod je prek Moravč lahek dostop v Ljubljansko kotlino, preko Vač pa je možen ponoven vstop v dolino Save zahodno od Litije. ${ }^{1}$

\footnotetext{
${ }^{1}$ Draksler 2007, 121.
}

Na levem bregu potoka Medija je bilo ob vznožju Ocepkovega hriba na Cesti Borisa Kidriča v Zagorju ob Savi odkrito arheološko najdišče ( $s l$. 1: 1). Teren zlagoma pada proti jugovzhodu ter strmo proti potoku Medija na zahodu, kjer so $\mathrm{v}$ pobočju vidne terase, katerih starost nam ni znana. Geološka osnova je na območju arheoloških izkopavanj dolomit, ki ga je prekrivala tudi do 2 $\mathrm{m}$ debela plast nasutij in naplavinskih nanosov. ${ }^{2}$

Grobišče iz starejše železne dobe na lokaciji današnje Ceste Borisa Kidriča v Zagorju ob Savi je bilo odkrito že v 19. stoletju, ko so na dan prišle najdbe ob gradnji Milačeve hiše in sosednjih stavb. Nekaj grobov je bilo odkritih tudi leta $1954 \mathrm{ob}$ prenovi te ceste. Na osnovi muzejskih inventarnih

2 M. Murko, Poročilo o arheoloških izkopavanjih na najdišču Zagorje - Kidričeva cesta, 2011, neobjavljeno poročilo, hrani ga podjetje PJP. Najdbe začasno hrani PJP. 


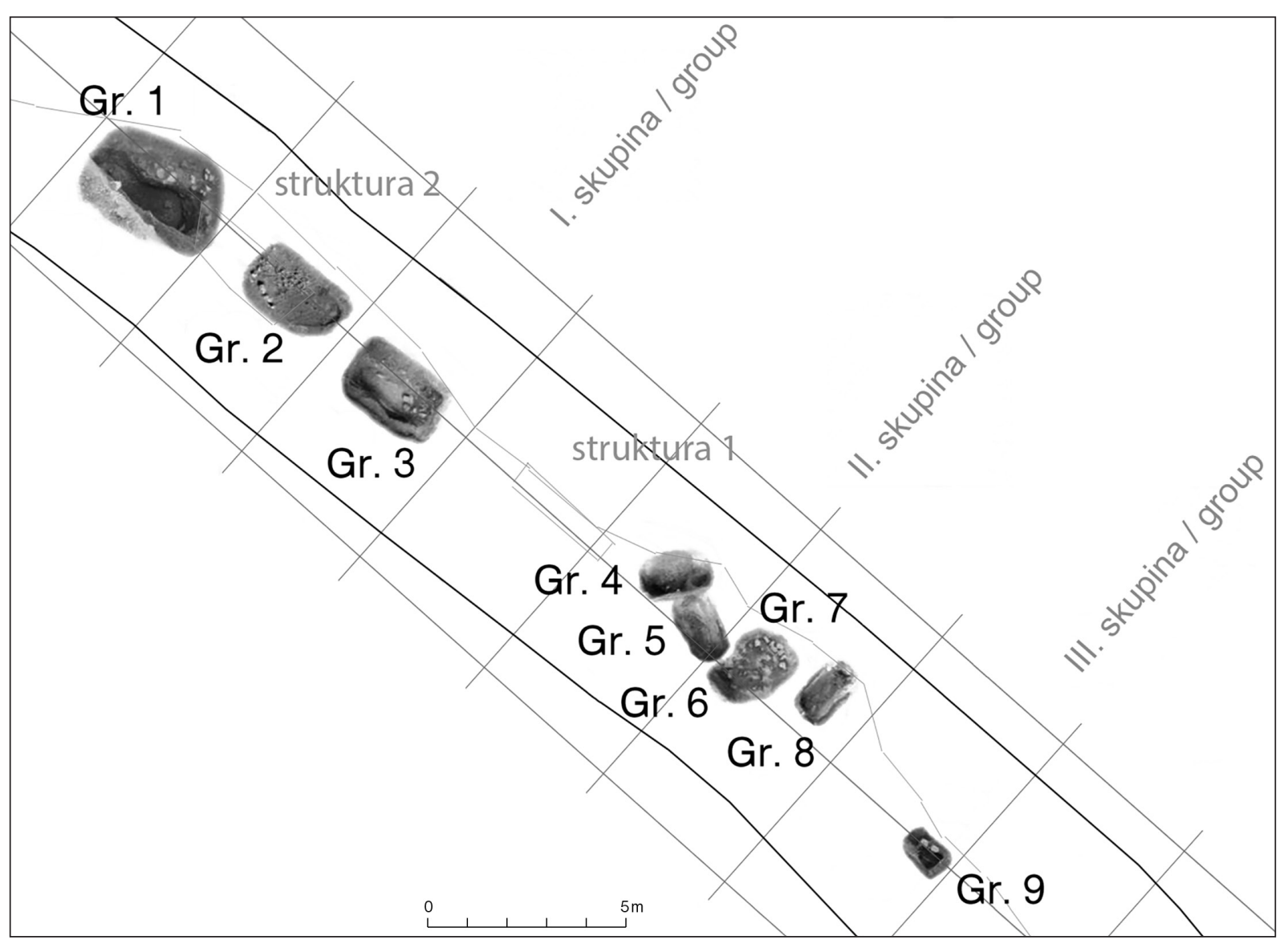

Sl: 2: Zagorje ob Savi - Cesta B. Kidriča. Lega grobov na območju izkopa leta 2011. M. = 1:200.

Fig. 2: Zagorje ob Savi - Cesta B. Kidriča. Plan of the area excavated in 2011. Scale = 1:200.

knjig in poročil o teh odkritjih je Stane Gabrovec dognal, da sodijo halštatske najdbe, ki jih hrani Narodni muzej Slovenije, po vsej verjetnosti k 12 skeletom. ${ }^{3}$ Zagotovo je bilo v preteklosti odkritih še več grobov, saj je po pripovedovanju domačinov v zasebni lasti še nekaj najdb, o katerih ne govori nobeno poročilo. ${ }^{4}$

Spomladi 2011, točneje 25. maja, je domačinka iz Zagorja ob Savi obvestila pristojno območno enoto Zavoda za varstvo kulturne dediščine Slovenije (ZVKDS) v Ljubljani o najdbi bronaste zapestnice, ki jo je opazila na kupu odpadne zemljine med gradnjo komunalne infrastrukture na Cesti Borisa Kidriča. Ob ogledu terena je arheološka ekipa pod vodstvom Mateja Drakslerja popisala stanje in ugotovila nekaj delno poškodovanih grobov

${ }^{3}$ Gabrovec 1966.

4 Draksler 2007, 131. Očividec je M. Drakslerju pripovedoval o številnih grobovih in predmetih, ki so prišli na dan leta 1953 ob gradnji temeljev Delavskega doma. Lepši, kovinski predmeti so menda končali po domovih vodilnih. Ostali udeleženci so takrat dobili jasna navodila, da novica o odkritju ne sme priti na ušesa arheologom. iz starejše železne dobe. Julija 2011 so sledila arheološka izkopavanja, ki so jih izvedli sodelavci podjetja PJP d.o.o. pod vodstvom Mihe Murka. Odkritih je bilo devet grobov, nekateri med njimi so bili skoraj popolnoma izropani.

\section{Plano grobišče na Cesti Borisa Kidriča}

Grobovi, odkriti na Cesti Borisa Kidriča, so bili razporejeni v tri skupine, pri čemer prvo skupino sestavljajo grobovi 1, 2, 3, drugo grobovi 4, 5, 6, 7 in 8 , tretjo pa morebiti predstavlja grob 9 , ki je bil nekoliko odmaknjen od ostalih (sl. 2). Grobne jame so bile vkopane v naplavinsko plast in preperino dolomita. V večini primerov je bila grobna jama obdana s kamni. Od devetih grobov so bila okostja ohranjena $\mathrm{v}$ šestih primerih, medtem ko so bila v ostalih skoraj povsem uničena. Grob 9 je bil presekan $\mathrm{z}$ izkopom jarkov za kanalizacijo in vodovod, grob 2 pa je bil najverjetneje poškodovan pri gradnji ceste $\mathrm{v}$ petdesetih letih prejšnjega 
stoletja. V celoti sta bila ohranjena le grobova 5 in $8 . \mathrm{V}$ grobnih jamah, ki niso bile izropane, so se poleg ostankov skeletov ohranili različni grobni pridatki. Usmerjenost grobov je bila različna in očitno prilagojena padcu terena. Ležali so vzporedno ali pa pravokotno na pobočje. Glede na grobne pridatke in analize kostnih ostankov so grobovi 2, 3 in 9 opredeljeni kot moški, grobova 6 in 7 kot otroška, grobova 5 in 8 pa kot ženska. ${ }^{5}$

\section{I. skupina grobov}

Grobovi I. skupine so bili močno poškodovani in skoraj povsem izropani. Morda so jih izpraznili že ob prvi pozidavi prostora $\mathrm{v}$ 19. stoletju ali pa so bili poškodovani ob obnovi ceste $\mathrm{v}$ petdesetih letih prejšnjega stoletja. Impresivne velikosti grobnih jam grobov 1 in 3 ter posamezni predmeti, najdeni v zasutjih grobov, pričajo o potencialno bogatih grobovih. Ohranjeni jami sta bili globoko vkopani, saj je bil teren ob obnovi ceste znižan za okoli $2 \mathrm{~m}$.

\section{Grob 1}

Grobna jama: v tlorisu oglate oblike, dol. $370 \mathrm{~cm}$, šir. 170 $\mathrm{cm}$, gl. $60 \mathrm{~cm}$. Pod več plastmi zemljenih nasutij so bili odkriti ostanki kamnite grobne obloge.

Opomba: v zasutju grobne jame so bili najdeni odlomki keramike (t. 2: 10-16) in fragment goveje kosti. ${ }^{6}$

\section{Grob 2}

Grobna jama: ni bila ohranjena. Položaj groba je bilo mogoče ugotoviti le na osnovi lege kosti sicer slabo ohranjenega skeleta, od katerega se je ohranilo nekaj dolgih kosti od medenice navzdol. Ob levi nogi sta ležali certoški fibuli (sl. 3). Preminuli je bil položen na hrbet.

Spol: moški.

Pridatki: par bronastih certoških fibul (t. 1: 1,2).

Opomba: v zasutju grobne jame je bil najden odlomek lonca (t. 2: 17).

\section{Grob 3}

Grobna jama: v tlorisu oglate oblike, dol. $239 \mathrm{~cm}$, šir. 112 $\mathrm{cm}$, gl. $60 \mathrm{~cm}$. Pod več plastmi zemljenih zasutij so bili ohranjeni ostanki kamnite grobne obloge. V zasutju groba je bila večja količina oglja. Na dnu grobne jame so ležali štirje bronasti gumbki.

Spol: moški.

Pridatki: štirje bronasti gumbi ( $t$. $1: 3-6)$.

Opomba: v zasutju grobne jame so bili najdeni odlomki loncev, ročaja pekev in svitka (t. 3: 1-5).

\footnotetext{
5 Tatjana Tomazo-Ravnik, Strokovno poročilo o obdelavi kostnega gradiva iz Zagorja ob Savi, Cesta Borisa Kidriča, Kamnik 2011, neobjavljeno poročilo, hrani ga podjetje PJP. Osteološke najdbe začasno hrani PJP.

${ }^{6} \mathrm{Za}$ analize kosti glej članek: R. A. Nicholls, J. Buckberry, M. Črešnar, I. Armit, Ph. Mason in H. Koon v tej številki Arheološkega vestnika.
}

\section{II. skupina grobov}

Kot je pokazala analiza ohranjenih delov okostij, sestavljajo to skupino en moški (gr. 4), dva ženska (gr. 5 in 8) in dva otroška pokopa (gr. 6 in 7). Morda je šlo za pokope družinskih članov.

\section{Grob 4}

Grobna jama: v tlorisu oglate oblike z zaobljenimi vogali, dol. $196 \mathrm{~cm}$, šir. $120 \mathrm{~cm}$, gl. $30 \mathrm{~cm}$. Pod zemljenim nasutjem so bili ostanki kamnite obloge grobne jame. Grob je bil izropan, le na dnu so bili posamezni delci okostja. Spol: moški.

Opomba: v zasutju grobne jame so bili najdeni kamnito orodje in odlomka loncev ( $t$. 3: 6-9).

\section{Grob 5}

Grobna jama: v tlorisu oglate oblike z zaobljenimi vogali, dol. $190 \mathrm{~cm}$, šir. $90 \mathrm{~cm}$, gl. $50 \mathrm{~cm}$. Pod zemljenim zasutjem je bil na dnu grobne jame dobro ohranjen skelet. Ohranjene so bile skoraj vse kosti in tudi nekaj zob. Preminula je bila položena na hrbet, roke je imela iztegnjene ob telesu, noge pa prekrižane, glava je bila obrnjena $\mathrm{v}$ levo. Ob desno stran glave je bila pridana posoda (sl. 4).

Spol: ženski.

Pridatki: keramični lonček ( $t$. 1: 9).

Opomba: v zasutju grobne jame so bili najdeni odlomek lonca (t. 2: 18) in dve goveji kosti (gl. op. 6).

\section{Grob 6}

Grobna jama: v tlorisu pravokotne oblike, dol. $100 \mathrm{~cm}$, šir. $60 \mathrm{~cm}$, gl. $80 \mathrm{~cm}$. Jamo so obdajali veliki dolomitni kamni (sl. 5). V njej je bil slabo ohranjen skelet s koščki bronaste zvite žice na prsnem delu.

Starost: otroški.

Pridatki: bronasta zvita žica ( $t .1: 10)$.

\section{Grob 7}

Grobna jama: v tlorisu pravokotne oblike, dol. $120 \mathrm{~cm}$, šir. $80 \mathrm{~cm}$, gl. $50 \mathrm{~cm}$ (sl. 5). Jamo je obdajal venec iz velikih dolomitnih kamnov. V njej je bil odkrit skelet, ki je imel na roki bronasto zapestnico, v predelu vratu pa koščeno jagodo.

Starost: otroški.

Pridatki: bronasta zapestnica ( $t$. 1: 8) in koščena jagoda (t. 1: 7).

\section{Grob 8}

Grobna jama: v tlorisu oglate oblike z zaobljenimi vogali, dol. $200 \mathrm{~cm}$, šir. $90 \mathrm{~cm}$, gl. $60 \mathrm{~cm}$. Pod zemljenim zasutjem je bil na dnu jame odkrit dobro ohranjen skelet. Ohranjene so bile prav vse kosti in tudi nekaj zob. Preminula je bila položena na hrbet, roke je imela iztegnjene ob telesu, noge prekrižane, glavo pa obrnjeno v levo. Pri desnem kolenu je ležala kačasta fibula, levo ob glavi so bile položene posoda in jantarne jagode, na glavi pa bronast lasni obroček. Grob je obdajala kamnita obloga (sl. 6).

Spol: ženski. 


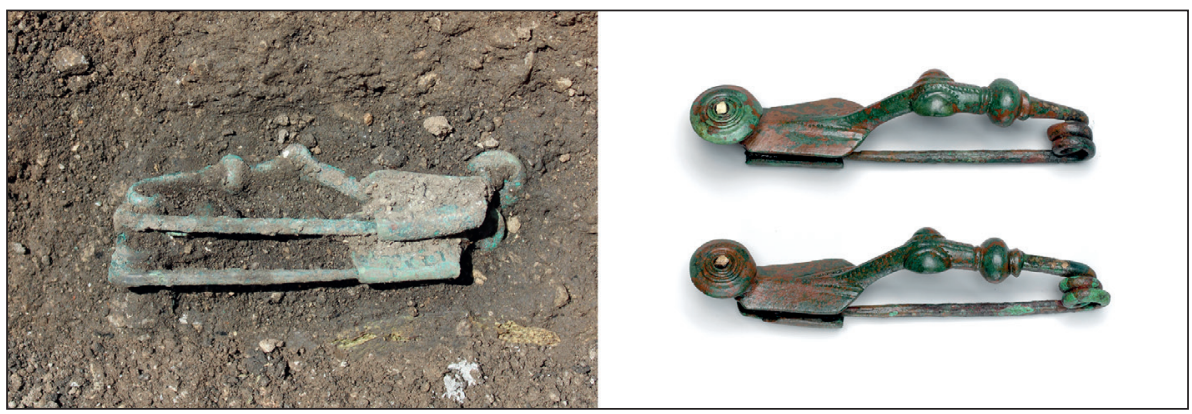

Sl. 3: Zagorje ob Savi - Cesta B. Kidriča. Grob 2: certoški fibuli in situ in po čiščenju. Fig. 3: Zagorje ob Savi - Cesta B. Kidriča. Grave 2: pair of Certosa fibulae, in situ and after cleaning.

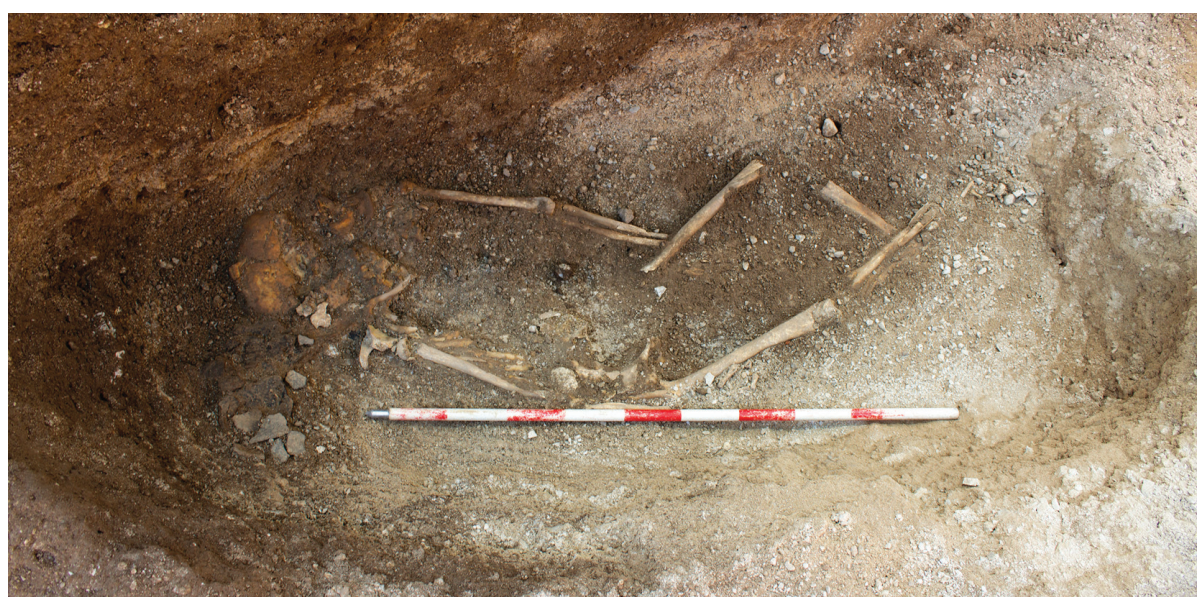

Sl. 4: Zagorje ob Savi - Cesta B. Kidriča. Grob 5: okostje s keramično posodo (t. 1: 9) ob glavi. Pogled z jugozahoda.

Fig. 4: Zagorje ob Savi - Cesta B. Kidriča. Grave 5: a female skeleton and a ceramic jar (Pl. 1: 9) beside the head. View from the southwest.

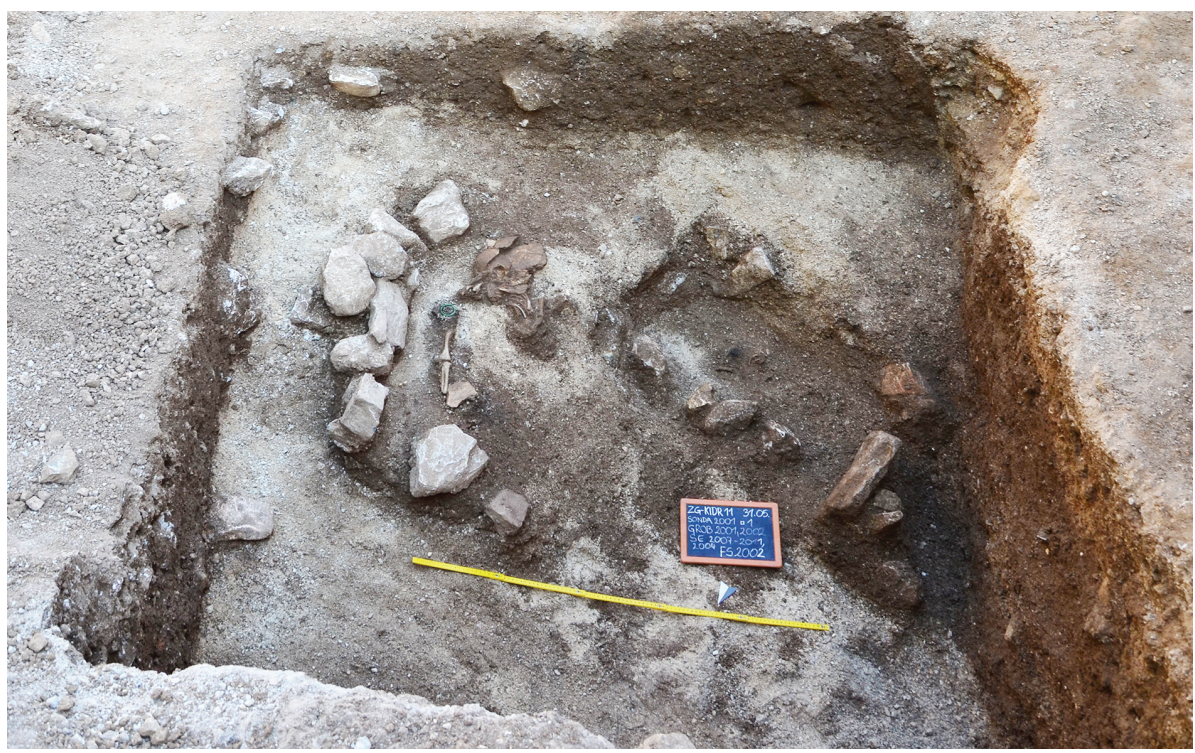

Sl. 5: Zagorje ob Savi - Cesta B. Kidriča. Otroška grobova (gr. 6, desno) in (gr. 7, levo) s kamnito oblogo. Pogled s severozahoda.

Fig. 5: Zagorje ob Savi - Cesta B. Kidriča. Children's Graves (Gr. 6, right) and (Gr. 7, left) with a stone lining. View from the northwest. 


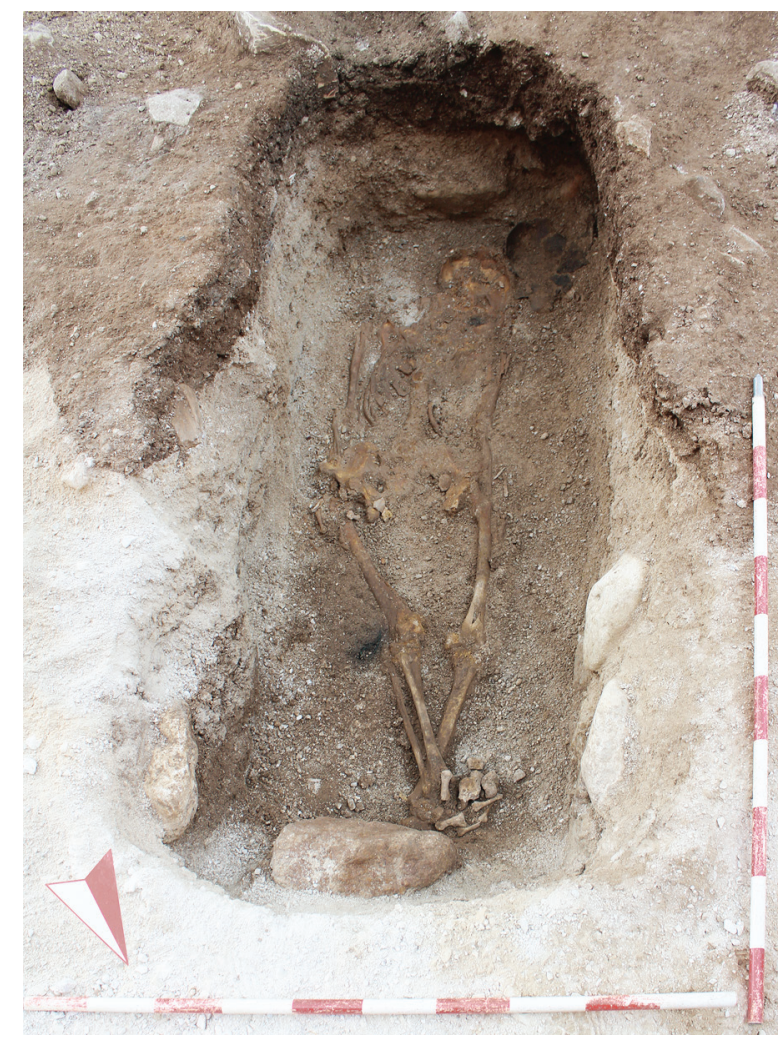

Sl. 6: Zagorje ob Savi - Cesta B. Kidriča. Ženski grob 8: kamnita obloga, okostje in pridatki. Pogled s severovzhoda. Fig. 6: Zagorje ob Savi - Cesta B. Kidriča. Female Grave 8: stone lining, skeleton and grave goods. View from the northeast.

Pridatki: bronasta kačasta fibula (t. 2: 2), lasni obroček (t. 2: 1), pet jantarnih jagod (t. 2: 3) in keramična posoda (t. 2: 4).

Opomba: v zasutju grobne jame sta bili najdeni prašičji kosti (gl. op. 6).

\section{III. skupina grobov}

V tretjo skupino uvrščamo grob 9 zaradi manjšega odmika od II. skupine grobov.

\section{Grob 9}

Grobna jama: z izkopom kanalizacijskega jarka je bila presekana na pol; v tlorisu je bila oglate oblike, dol. 86 $\mathrm{cm}$, šir. $58 \mathrm{~cm}$, gl. $38 \mathrm{~cm}(s l .7)$. Pod zemljenim zasutjem je bil odkrit le delno ohranjen skelet (medenični obroč, dolge nožne kosti brez stopal). Preminuli je bil hrbtno položen v grob. Deli pasne garniture so ležali na desni stegnenici in ob njej. Morda bi lahko temu grobu pripisali tudi sporadično najdeno železno sulično ost $\mathrm{v}$ njegovi bližini (t. 2: 9).

Spol: moški.

Pridatki: bronasta pasna spona ( $t .1: 15)$, bronasti sponki $(t$. 1: 11,12), bronast obroček $(t .1: 13)$ in koščena jagoda ( $t$. 1: 14).

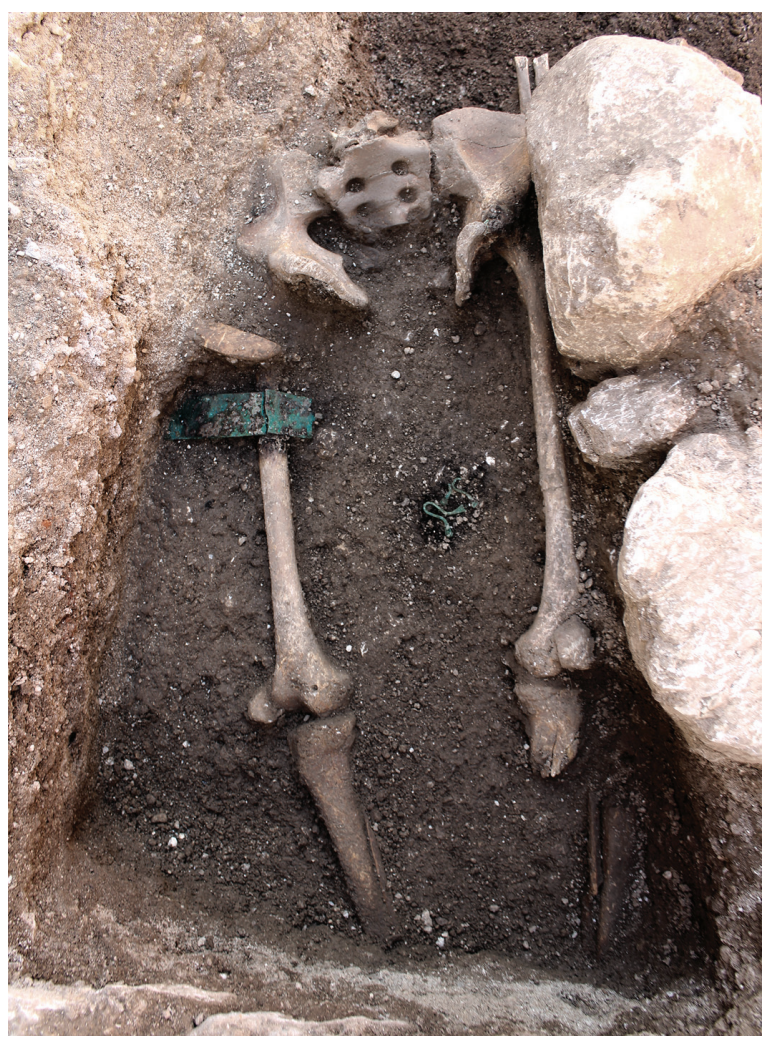

Sl. 7: Zagorje ob Savi - Cesta B. Kidriča. Moški grob 9: okostje in pasna garnitura in situ. Pogled z jugovzhoda. Fig. 7: Zagorje ob Savi - Cesta B. Kidriča. Male Grave 9: skeleton and belt in situ. View from the southeast.

Opomba: v zasutju grobne jame so bili najdeni odlomka keramičnega vretenca in dna posode $(t .2: 19,20)$ ter jelenja kost (gl. op. 6).

Arheološka odkritja na Cesti Borisa Kidriča v Zagorju ob Savi dopolnjujejo doslej znano sliko grobišča iz starejše železne dobe. Devet odkritih grobov variira od preprostih vkopanih jam, v katere so bili priloženi le skromni grobni pridatki, do bogatejših, katerih grobna jama je bila obdana s kamnito oblogo in je bilo v njih večje število pridatkov. Podobno velja za ohranjenost grobov, saj so bili nekateri dobro ohranjeni (gr. 5 in 8), drugi pa močneje poškodovani (gr. 1, 2, 3, 4 in 9).

Med grobovi I. skupine, ki ležijo na severozahodnem delu grobišča na najvišji točki ceste (sl. 2 ), izstopata po velikosti grobnih jam grobova 1 in 3, ki dajeta slutiti, da gre za bogata, verjetno moška pokopa, vendar sta povsem uničena. $\mathrm{V}$ grobu 1 pridatki niso bili najdeni, $\mathrm{v}$ grobu 3 so se ohranili le štirje bronasti gumbi $(t$. $1: 3-6)$, tisti z jamico na kapici ( $t .1: 3$ ) ima dobre primerjave na Molniku v moškem grobu 13/2, datiranem v negovsko stopnjo, kjer so bili taki gumbi pritrjeni 
na pasico, spleteno iz usnjenih trakov. ${ }^{7} \mathrm{~V}$ grobu 2 sta bili in situ ohranjeni le certoški fibuli XII. vrste po Teržanovi (sl. 3 ; t. 1: 1,2), ki so v dolenjski halštatski skupini značilne za negovski horizont. ${ }^{8}$ Posebnost tega para fibul je, da sta bila njuna gumba okrašena z vstavljenimi koralami. Poleg tega je bila noga ene izmed njiju popravljena, saj je bil nov del prikovan s tremi bronastimi zakovicami, zaradi česar sklepamo, da sta bili del dragocenega nakita.

Bolje so bili ohranjeni grobovi II. skupine. Grobne jame so bile vkopane globoko pod naplavinskimi plastmi, a so bile slabo vidne. Kljub temu je bil grob 4, od katerega se je ohranila kamnita obloga, skoraj popolnoma izpraznjen. Izstopa grob 8 , v katerem je bila pokopana odrasla ženska, ki je imela poleg jantarnih jagod še lasni obroček iz trakaste žice $\mathrm{z}$ vzdolžno kaneluro in pregibom, kačasto fibulo $\mathrm{z}$ diskom in posodo (t. 2: 1-4). Takšne fibule $\mathrm{z}$ diskom na prehodu igle $\mathrm{v}$ lok, ki je vlit in nataknjen, uvršča Tecco Hvala v svoji tipološki členitvi v tip IVb. Izvorno območje kačastih fibul tipa IV smemo iskati na ozemlju Slovenije, kjer se pojavljajo v 6 . st. pr. n. št. ${ }^{9} \mathrm{~V}$ dolenjski noši tega časa so tipičen element in se pojavljajo tudi $\mathrm{v}$ kombinaciji z lasnimi obročki iz trakaste žice in vzdolžno kaneluro ter pregibom, ${ }^{10}$ enako kot v grobu 8 iz Zagorja ob Savi.

$\mathrm{V}$ grobu 5 je bila prav tako pokopana odrasla ženska, ob glavo so ji položili lonec ( $t$. 1: 9). Med ženskima grobovoma sta ležala otroška, v grobu 6 je bil pokopan otrok, star okoli tri mesece (Infans $I$ ), v grobu 7 pa enoletni otrok (Infans I). Pri prvem so bili najdeni koščki zvite bronaste žice $(t .1: 10)$, drugi je imel na zapestju bronasto zapestnico $(t$. 1: 8) in na vratu koščeno jagodo (t. 1:7).

Grob 9 odraslega moškega je ležal najbližje grobovom, ki so bili odkriti v letih med 1894 in 1896 na območju Milačeve hiše (sl. 1: 2). Opravljen je bil s pasno garnituro ( $t$. 1: 11-15), ki sodi k značilni moški opravi certoškega horizonta. ${ }^{11}$ Časovno se pokop ujema s skupino grobov pri Milačevi hiši, med katerimi je izstopal bogat moški grob s figuralno okrašeno pasno spono in situlo ter standardno opremo bojevnika (sulici, bojna sekira), pokopan pa je bil skupaj s konjem in skitsko konjsko opremo. ${ }^{12}$

\footnotetext{
7 Tecco Hvala 2017, 111, sl. 96, t. 9: 4.

8 Teržan 1976, 365.

9 Tecco Hvala 2014, 131, 150.

10 Prim. Tecco Hvala 2012, 327 s, sl. 122: 4.

11 Gabrovec 1966, t. 7: 3; 8: 5.

12 Ib., t. 5: $10 ; 7: 3 ; 8: 1$ (ali 2),3,4.
}

Glede na novo pridobljene najdbe domnevamo, da so na območju današnje Ceste Borisa Kidriča v Zagorju ob Savi (sl. 1: 1) pričeli pokopavati v času kačastega horizonta. Pokopavanje se je nadaljevalo $\mathrm{v}$ negovski horizont, kamor sodijo grobovi prve skupine, umaknjeni na skrajni rob ob skalno steno, kjer za nadaljnje širjenje grobišča ni več primernega prostora. Morda so zaradi tega svoje umrle pričeli pokopavati na drugem kraju - na nasprotni strani Ocepkovega hriba, na območju današnje Levstikove ulice (sl. 1: 3), od koder so ohranjeni predmeti iz dveh latenskodobnih grobov. ${ }^{13}$

\section{Naselbinski ostanki na Cesti Borisa Kidriča}

Na območju grobov so bili z arheološkimi izkopavanji leta 2011 odkriti tudi številni kosi razbite lončenine, ki je starejša. Odgovor na vprašanje, kako te najdbe razložiti, ni preprost. Po celotni dolžini izkopnega polja so prečno na pobočje vidne terase (sl. 8), ki so jih sčasoma prekrili naplavinski nanosi z Ocepkovega hriba (sl. 1: 4). V nanosih je bilo veliko kosov lončenine in drugih najdb, ki nakazujejo časovni razpon od pozne bronaste do starejše železne dobe, vendar ne kontinuirano. Širina izkopa in uničenost arheološkega najdišča nista omogočali dobrega vpogleda $\mathrm{v}$ stratigrafijo, zato je maloštevilne in močno poškodovane ostaline zelo težko opredeliti. Ni izključeno, da te najdbe izvirajo z Ocepkovega hriba, kjer se domneva prazgodovinska naselbina.

Severno od II. skupine grobov je bila odkrita vrsta kamnov (sl. 2: struktura 1), za katero menimo, da je morda ostanek temelja stavbe ali pa utrditev brežine terase (temelj škarpe). Tu je bila najdena bronasta trortasta fibula ( $t$. 2: 5), ki jo lahko pripišemo VII. vrsti po Ogrinovi in predstavlja najmlajšo obliko trortastih fibul, ki se v dolenjski halštatski skupini pojavlja $\mathrm{v}$ grobovih certoške stopnje. ${ }^{14}$ Fibula te vrste s Ceste Borisa Kidriča v Zagorju ob Savi bi lahko izvirala iz enega od uničenih grobov.

Kamnita groblja je bila odkrita tudi na območju I. skupine grobov (sl. 2: struktura 2; sl. 9), poškodoval pa jo je vkop jame groba 2 . Na tem mestu smo pri izkopavanju naleteli na veliko količino keramičnih najdb ( $t$. 3: 10-15; 4: 1-6), železove žlindre, hišnega

13 Draksler 2007, 132-133.

14 Ogrin 1998, 113, 125, sl. 15, 37. Glej še Tecco Hvala 2012, 218 ss, sl. 84: 7. 


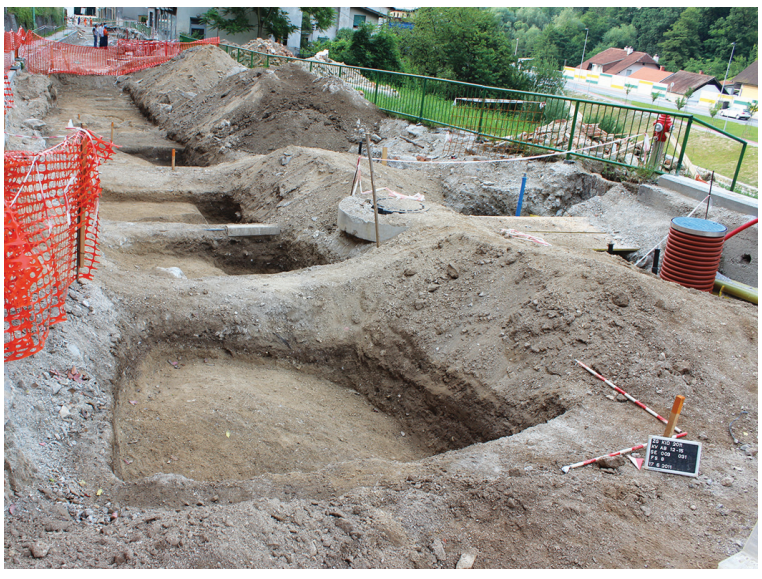

Sl. 8: Zagorje ob Savi - Cesta B. Kidriča. Izkopane terase v kvadrantih A/B 10-17. Pogled z severozahoda.

Fig. 8: Zagorje ob Savi - Cesta B. Kidriča. Excavated terraces in Grid Squares A/B 10-17. View from the northwest.

ometa in živalskih kosti. Ker te najdbe kažejo na naselbinski značaj, ne izključujemo možnosti, da gre za ostanke poselitve na terasi.

Odkritje v vrste zloženih kamnov, morda temeljev stavb, in kulturnih plasti z najdbami naselbinskega značaja dopušča domnevo, da je na raziskanem prostoru najprej obstajala naselbina in nato grobišče. Naselbinske najdbe namreč datiramo v pozno bronasto oziroma starejšo železno dobo. Na podlagi količine žlindre pa bi lahko sklepali, da je v bližini potekala tudi predelava železove rude.

Med najdbami prevladuje keramika, predvsem lonci ( $t$. $2: 15,16 ; 3: 1,2,12-15 ; 4: 7,11)$ in latvice (t. $4: 5,15,18)$. Številni so svitki $(t .2: 11 ; 3: 5 ; 4$ : $1-4,24,25,28)$, ročaji pekev $(t .3: 3,4 ; 4: 23)$ in keramična vretenca $(t .2: 19 ; 4: 20)$, ki sodijo med značilen inventar prazgodovinskih hiš. Podobno velja tudi za kamnita orodja iz roženca $(t .3: 7,8,10)$.

Posebno pozornost vzbuja fragment dna posode s stožčasto apliko na notranji strani ( $t: 2: 20)$. Anja Hellmuth takšne posode iz bronastodobne naselbine Monkodonja pri Rovinju v Istri povezuje s predelavo mleka oziroma izdelavo masla; ${ }^{15}$ na bronastodobnih najdiščih v Bosni pa jih povezujejo $\mathrm{z}$ metalurško dejavnostjo. ${ }^{16}$

Keramika je bolj skromno okrašena. Prevladujejo nalepljena razčlenjena rebra ( $t$. 2: 10,12-14; 4: 7,9,13,14,17), ki so kronološko manj povedna, ter vrezi (t. $2: 17 ; 4: 6,16)$, odtisi (t. $2: 15 ; 3: 1)$, vbodi $(t .4: 10)$ in aplike (t. 2: 4). Ohranilo se je

\footnotetext{
15 Hellmuth 2014, 76.

16 Čović 1984, 128-129.
}

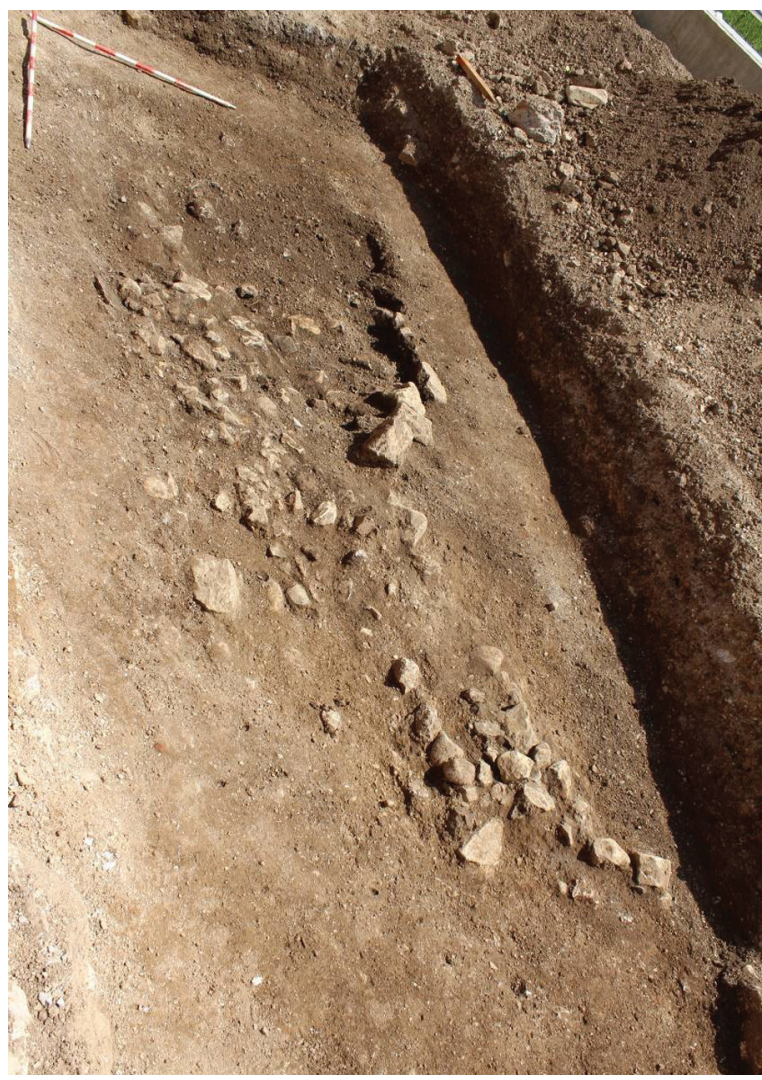

Sl. 9: Zagorje ob Savi - Cesta B. Kidriča. Pogled na kamnito grobljo na območju grobov I. skupine $\mathrm{z}$ vidnim vkopom grobne jame 2. Pogled s severovzhoda.

Fig. 9: Zagorje ob Savi - Cesta B. Kidriča. Heap of stones in the area of the first cluster of burials with the pit of Grave 2 visible at the top. View from the northeast.

nekaj držajev ( $t .4: 12)$, nekateri so tudi razčlenjeni (t. 2: 18).

Keramičnim oblikam in okrasu je mogoče najti primerjave med naselbinskimi najdbami s Kučarja pri Podzemlju v Beli krajini ${ }^{17}$ in z železnodobnega gradišča na Libni v Posavju. Časovno je morda pomemben fragment posode, okrašen $\mathrm{z}$ vrezanimi trikotniki ( $t$. 4: 16). Posode s podobnim ornamentom so na Kučarju pri Podzemlju opredeljene na začetek halštatskega obdobja. ${ }^{18}$

Že bežen pregled keramičnih najdb iz Zagorja ob Savi pokaže, da imamo opraviti z dvema oziroma več časovnimi horizonti. Večini najdb lahko pripišemo naselbinski značaj in jih uvrstimo na začetek starejše železne dobe (npr. t. 2: 18; 4: 16). Med mlajše oblike pa spadajo na primer fragmenti pitosa in ciborija $(t .3: 11 ; 4: 21)$, ki sodijo $\mathrm{v}$ zvrst posodja, kakršno je bilo $\mathrm{v}$ rabi v dolenjski halštat-

\footnotetext{
17 Dular, Ciglenečki, Dular 1995, t. 1-77.

18 Ib., t. 1: 18; 8: 12; 29: 2,12; 49: 3; 69: 1; 70: 2.
} 


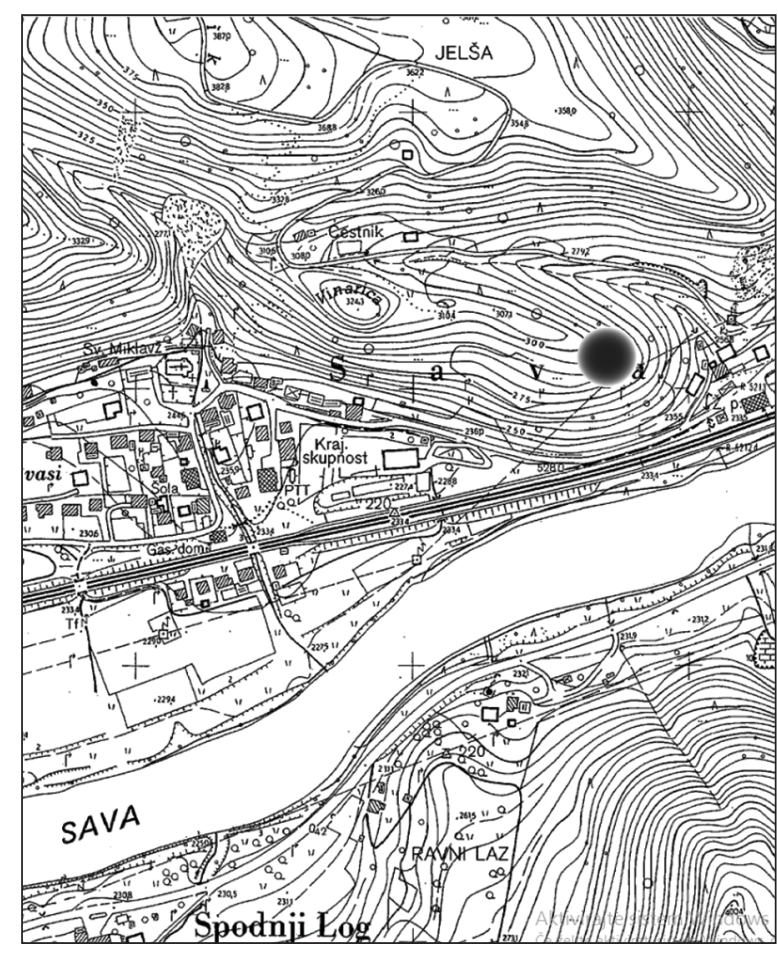

Sl. 10: Sava pri Litiji. Lokacija najdbe sulične osti in pavkaste fibule.

Fig. 10: Sava near Litija. Marked findspot of the spear and kettledrum fibula.

(Vir / Source: GURS@TTN 5, Litija 24).

ski skupini predvsem $\mathrm{v}$ kačastem in certoškem horizontu. ${ }^{19}$ Glede na najdiščne okoliščine bi lahko sklepali, da sta bila ciborij in pitos morda grobna pridatka in so se njune črepinje pomešale $\mathrm{z}$ naselbinskimi najdbami iz starejše halštatske dobe zaradi kasnejših zemeljskih del, ki so poškodovala grobišče.

\section{SAVA PRI LITIJI}

Nad Savo pri Litiji (sl. 10) sta bili pri gradbenih delih za postavitev bazne postaje in za dovozno pot naključno odkriti bronasta fibula in železna sulična ost (sl. 11). Najditelj ju je predal v hrambo Mestnemu muzeju v Litiji in $\mathrm{z}$ arheologom Matejem Drakslerjem opravil ogled lokacije. Ob terenskem ogledu so bila gradbena dela že zaključena, zato možnosti za natančnejšo opredelitev najdiščnih okoliščin ni bilo. Najdbi sta bili odkriti na skrajnem jugovzhodnem robu nizke vzpetine Vinarica (sl. 10), ki se kot ozek greben razteza tik nad reko Savo. Greben je dolg približno $250 \mathrm{~m}$, širok približno

\footnotetext{
${ }^{19} \mathrm{Ib} ., 23$.
}

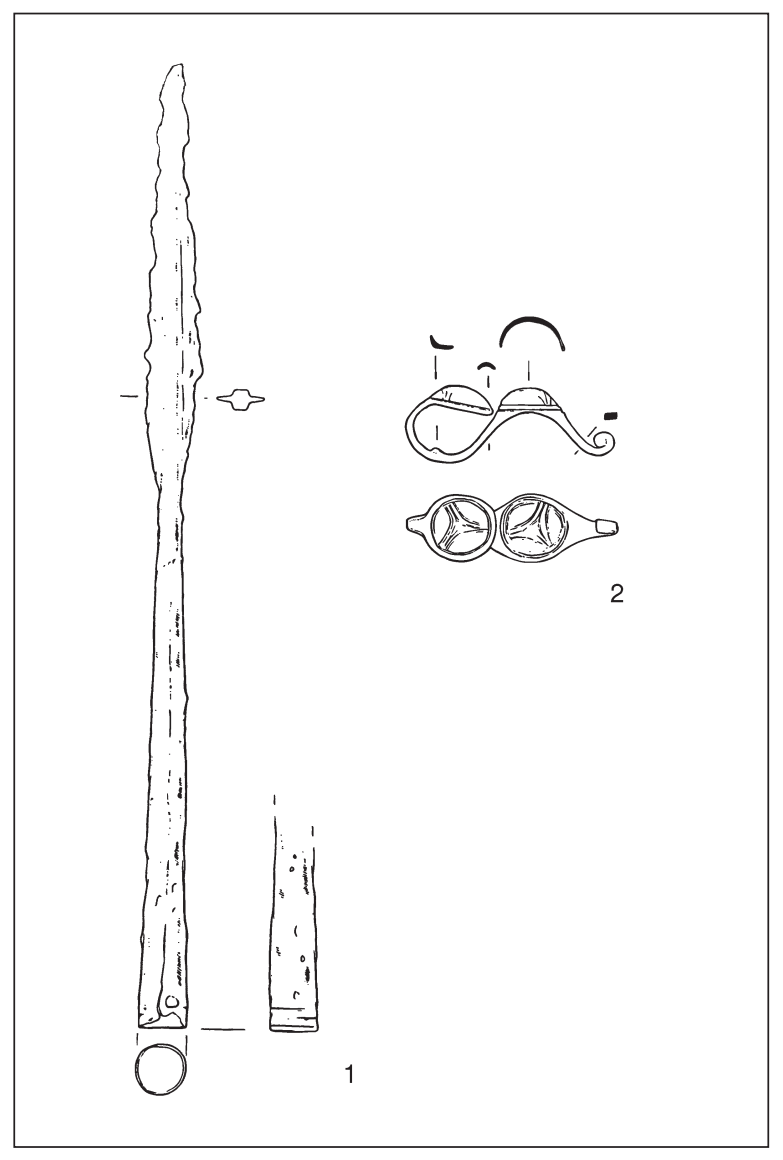

Sl. 11: Sava pri Litiji. Naključni najdbi. 1 železo; 2 bron. M. $1=1: 4 ; 2=1: 2$.

Fig. 11: Sava near Litija. Chance finds. 1 iron; 2 bronze. Scale $1=1: 4 ; 2=1: 2$.

$20 \mathrm{~m}$ in se v smeri jugovzhod-severozahod dvigne za približno $50 \mathrm{~m}$, najvišjo točko $(324,3 \mathrm{~m})$ doseže na skrajnem severozahodnem delu.

Naključno odkriti najdbi sta bila verjetno grobna pridatka, ki nakazujeta, da je bilo tu grobišče. ${ }^{20}$ Bronasto dvojnopavkasto fibulo (nem. Doppelpaukenfibel) s polkrožnim presekom pavk, okrašenih s polkrožnimi rebri oziroma žlebiči (sl. 11: 2), uvrščamo med tako imenovane Alpine Blech-paukenfibeln $\mathrm{z}$ najboljšimi paralelami v južnoalpskih dolinah. ${ }^{21}$ Južnoalpska izvedba tovrstnih fibul se pojavlja na najdiščih od Zgornjega Poadižja prek Koroške do Posočja in Dolenjske; največ pavkastih fibul v Sloveniji pa je znanih z Mosta na Soči, kjer so datirane $\mathrm{v}$ drugo polovico 5. st. pr. n. št. ${ }^{22}$

20 Ministrstvo za kulturo RS, Register nepremične kulturne dediščine: EŠD 29754 Sava - Železnodobno grobišče Vinarica.

21 Tecco Hvala 2012, 266.

22 Laharnar 2018, 206. 
Sulična ost (sl. 11: 1) ima najboljše primerjave na Dolenjskem, kjer se vitke sulične osti s krajšim listom in daljšim tulom pojavljajo v najmlajši stopnji halštatskega obdobja. ${ }^{23} \mathrm{Njihov}$ pojav časovno sovpada $z$ uporabo dvojnopavkastih fibul. Na podlagi tega domnevamo, da sta oba odkrita predmeta pripadala isti grobni celoti iz časa certoškega ali negovskega horizonta (5. st. pr. n. št.).

\section{ZAKLJUČEK}

Arheološka izkopavanja v letu 2011 na območju Ceste Borisa Kidriča v Zagorju ob Savi so prinesla nove podatke o najdišču, ki je znano že od konca 19. stoletja in je zaslovelo predvsem zaradi bronaste pasne spone $\mathrm{z}$ doslej edinstvenim prizorom lova. Pasno spono je objavil Stane Gabrovec skupaj s preostalimi najdbami iz starejših odkritij, ki jih hrani Narodni muzej Slovenije. ${ }^{24}$ Naša izkopavanja pa so poleg devetih grobov odkrila tudi naselbinske ostaline, ki jih datiramo $\mathrm{v}$ čas pozne bronaste in zgodnje železne dobe. Domnevamo, da je bilo območje grobišča predhodno poseljeno.

Od devetih grobov so bili trije uničeni. Med ohranjenimi grobnimi jamami sta bili daleč največji jami grobov 1 in 3, kar dopušča domnevo, da sta bila v njih pokopana tedanja veljaka. Bolje so bili ohranjeni grobovi 5, 6, 7, 8 in 9, ki so imeli tudi kamnito oblogo oziroma venec. Zanimiva se zdi II. skupina grobov, za katero menimo, da bi lahko bili tam pokopani pripadniki tesno povezane skupnosti, verjetno družine. Najbogatejši je bil grob $9 \mathrm{z}$ bronasto pasno garnituro, izstopata pa tudi certoški fibuli iz groba 2, okrašeni s koralnimi vložki, kar je izjemno v okviru dolenjske halštatske skupine.

Za raziskave so prav tako pomembni sorazmerno dobro ohranjeni ostanki okostij, katerih analize lahko prispevajo nova dognanja o načinu življenja ljudi v mlajšem halštatskem obdobju. ${ }^{25}$

23 Tecco Hvala 2012, 123, 127.

24 Gabrovec 1966, 19-49.

25 Glej zgoraj, op. 6 (članek Nicholls et al. v tej številki Arheološkega vestnika). Osteološke analize človeških kostnih ostankov in analize stabilnih izotopov ogljika in dušika na človeških in živalskih kostnih ostankih so bile v sklopu projekta ENTRANS (Encounters and Transformations in Iron Age Europe) opravljene na Univerzi v Bradfordu (Združeno kraljestvo). Projekt ENTRANS je finančno podprl raziskovalni program HERA (www.heranet.info), ki so ga soustanovili AHRC, AKA, BMBF via PT-DLR, DASTI, ETAG, FCT, FNR, FNRS, FWF, FWO, HAZU, IRC, LMT, MHEST, NWO, NCN, RANNÍS, RCN, VR in
Najdbi fibule in sulice, odkriti nad Savo pri Litiji, nam dodatno osvetljujeta fenomen planih skeletnih grobišč, ki ob koncu halštatskega obdobja povsem prevladujejo na območju med Vačami in Zagorjem ob Savi. Noša z doslej znanih zasavskih najdišč kaže dolenjski značaj, način pokopa pa odstopa od klasičnih dolenjskih gomil. V dolini Medije, ki je bila intenzivno poseljena šele $\mathrm{v}$ času mlajšega halštatskega obdobja, prevladujejo plana skeletna grobišča. ${ }^{26} \mathrm{~V}$ to sliko lahko sedaj vključimo še grobišče nad Savo pri Litiji, medtem ko provenienca dvojnopavkaste fibule nakazuje povezave tega prostora s severno Italijo.

\section{KATALOG}

Leta 2011 odkrite najdbe na območju Ceste Borisa Kidriča v Zagorju ob Savi začasno hrani podjetje PJP, najdbi iz Save pri Litiji pa Mestni muzej Litija.

Vsa v katalogu predstavljena lončenina je izdelana prostoročno; zrnatost gline in obdelava površine sta določeni po parametrih, ki jih je predlagala Milena Horvat. ${ }^{27}$

\section{Tabla 1}

\section{Grob 2}

1. Bronasta certoška fibula $z$ lokom zaobljeno rombičnega preseka, okrašenim na najvišjem delu z bradavičastima izrastkoma ter s kroglastim gumbom nad peresovino. Gumb na zaključku noge je okrašen s čepkom in koncentričnimi krožnimi vrezi. Čepek ima majhno jamico, v katero je bila vložena korala. Noga fibule je bila popravljena in prinetana $s$ tremi bronastimi neti.

2. Bronasta certoška fibula $z$ lokom zaobljeno rombičnega preseka, okrašenim na najvišjem delu $\mathrm{z}$ bradavičastima izrastkoma ter s kroglastim gumbom nad peresovino. Gumb na zaključku noge je okrašen s čepkom in koncentričnimi krožnimi vrezi. Čepek ima majhno jamico, v katero je bila vložena korala.

\section{Grob 3}

3. Bronast gumb z zanko in jamico na kapici.

4-6. Trije bronasti gumbi z zanko.

\section{Grob 7}

7. Koščena jagoda.

8. Bronasta zapestnica z razklenjenima koncema, okrašena s snopi vrezov.

Evropska komisija v sklopu OP7 2007-2013, v programu Socialno-ekonomske znanosti in Humanistika.

26 Draksler 2007, 151.

27 Horvat 1999, 16, 25. 


\section{Grob 5}

9. Odl. dna lonca z ostenjem; barva: zunaj sivo rjava, znotraj svetlo rdečerjava; površina: gladka; sestava: finozrnata.

\section{Grob 6}

10. Bronasta tanka zvita žica.

\section{Grob 9}

11-12. Bronasti zanki v obliki črke omega $\mathrm{z}$ dvema zakovicama.

13. Bronast obroček.

14. Koščena jagoda.

15. Pravokotna pasna spona iz bronaste pločevine. Okrašena je v kombinaciji vrezanega in punciranega geometrijskega motiva, ob desnem robu so ohranjene tri zakovice, na levem koncu je pločevina zakrivljena v kavelj.

\section{Tabla 2}

\section{Grob 8}

1. Fragm. bronast lasni obroček iz trakaste žice z vzdolžno kaneluro in pregibom.

2. Bronasta kačasta fibula $\mathrm{z}$ diskom.

3. Pet jantarnih jagod.

4. Lonček; barva: zunaj temno siva, znotraj sivorjava; površina: gladka; sestava: finozrnata; okras: podolgovata aplika.

\section{Sporadične najdbe}

5. Odl. bronaste trortaste fibule.

6-7. Bronasti zakovici.

8. Bronasta narebrena zapestnica s presegajočima koncema.

9. Železna sulična ost s tulom, ki je daljši od lista, ta ima poudarjeno sredinsko rebro.

\section{Iz zasutij grobov}

10. Odl. ostenja lonca; barva: sivorjava; površina: glajena; sestava: drobnozrnata; okras: vodoravno plastično rebro z odtisi prstov; v zasutju groba 1 .

11. Odl. svitka; barva: svetlo rdečerjava; površina: glajena; sestava: finozrnata; v zasutju groba 1 .

12. Odl. ostenja lonca; barva: zunaj svetlo rdečerjava, znotraj sivorjava; površina: glajena; sestava: drobnozrnata; okras: vodoravno plastično rebro z odtisi prstov; v zasutju groba 1 .

13. Odl. ostenja lonca; barva: zunaj rjava, znotraj temno rdečerjava; površina: glajena; sestava: drobnozrnata; okras: vodoravno plastično rebro $\mathrm{z}$ odtisi prstov; $\mathrm{v}$ zasutju groba 1 .

14. Odl. ostenja lonca; barva: zunaj rjava, znotraj črna; površina: glajena; sestava: finozrnata; okras: vodoravno plastično rebro z odtisi prstov; v zasutju groba 1.

15. Odl. ustja lonca; barva: zunaj rjavo rdeča, znotraj temno siva; površina: glajena; sestava: finozrnata; okras: odtisi nohtov pod robom ustja; v zasutju groba 1.

16. Odl. ustja lonca; barva: temno sivorjava; površina: glajena; sestava: finozrnata; v zasutju groba 1 .

17. Odl. ostenja lonca; barva: zunaj in znotraj svetlo sivorjava; površina: glajena; sestava: drobnozrnata; okras: dva vzporedna horizontalna žlebova; v zasutju groba 2.

18. Odl. ostenja lonca; barva: temno sivorjava; površina: glajena; sestava: finozrnata; okras: plastična aplika; v zasutju groba 5 .
19. Odl. vretenca; barva: črna; površina: glajena; sestava: finozrnata; v zasutju groba 9.

20. Odl. dna s stožčasto apliko; barva: zunaj svetlo rjava, znotraj temno siva; površina: gladka; sestava: finozrnata; v zasutju groba 9.

\section{Tabla 3}

\section{Iz zasutja grobov}

1. Odl. lonca $\mathrm{z}$ izvihanim ustjem; barva: zunaj sivorjava, znotraj rjavordeča; površina: zunaj brisana, znotraj glajena; sestava: finozrnata; okras: odtisi prstov na zunanjem robu ustja; v zasutju groba 3.

2. Odl. dna lonca; barva: zunaj svetlo rjava, znotraj temno rdeča; površina: zunaj brisana, znotraj glajena; sestava: finozrnata; v zasutju groba 3.

3. Odl. ročaja pekve; barva: sivo rjava; površina: glajena; sestava: grobozrnata; v zasutju groba 3.

4. Odl. ročaja pekve s čepom; barva: rdečerjava; površina: glajena; sestava: grobozrnata; v zasutju groba 3.

5. Odl. svitka; barva: svetlo rdeča; površina: glajena; sestava: finozrnata; v zasutju groba 3.

6. Odl. ostenja lonca; barva: zunaj svetlo sivorjava, znotraj rdeča; površina: glajena; sestava: finozrnata; v zasutju groba 4.

7. Kamnito orodje iz roženca; v zasutju groba 4.

8. Kamnito orodje iz roženca; v zasutju groba 4 .

9. Odl. dna lonca; barva: zunaj svetlo rdečerjava, znotraj temno sivorjava; površina: glajena; sestava: finozrnata; v zasutju groba 4.

\section{Iz kamnite groblje 2}

10. Kamnito orodje iz roženca; opomba: na straneh so vidne retuše.

11. Odl. ustja pitosa; barva: svetlo rdečerjava; površina: glajena; sestava: drobnozrnata; opomba: ustje je razčlenjeno in ima lepo viden utor za pokrov.

12. Odl. ustja lonca; barva: zunaj svetlo rdečerjava; površina: glajena; sestava: finozrnata.

13. Odl. dna lonca; barva: svetlo rjavordeča; površina: glajena; sestava: finozrnata.

14. Odl. ustja in ostenja lonca; barva: sivorjava; površina: glajena; sestava: finozrnata.

15. Odl. dna lonca; barva: zunaj zelo svetlo siva, znotraj svetlo sivorjava; površina: glajena; sestava: drobnozrnata.

\section{Tabla 4}

\section{Iz kamnite groblje 2}

1. Odl. svitka; barva: svetlo rdečerjava; površina: glajena; sestava: drobnozrnata.

2. Odl. svitka; barva: rdečerjava; površina: glajena; sestava: grobozrnata.

3. Odl. svitka; barva: svetlo rdečerjava; površina: glajena; sestava: drobnozrnata.

4. Odl. svitka; barva: svetlo sivorjava; površina: glajena; sestava: grobozrnata.

5. Odl. ustja latvice; barva: svetlo siva; površina: glajena; sestava: grobozrnata. 
6. Odl. ostenja lonca; barva: zunaj sivorjava, znotraj svetlo rjavordeča; površina: glajena; sestava: drobnozrnata; okras: dva vzporedna horizontalna žlebova.

\section{Iz zasutij teras}

7. Odl. ustja in ostenja lonca; barva: zunaj svetlo siva, znotraj svetlo sivorjava; površina: brisana; sestava: finozrnata; okras: vodoravno plastično rebro z odtisi prstov.

8. Odl. ustja lonca; barva: zunaj rdečerjava, znotraj sivorjava; površina: glajena; sestava: finozrnata.

9. Odl. ostenja lonca; barva: zunaj rdečerjava, znotraj sivorjava; površina: glajena; sestava: finozrnata; okras: vodoravno plastično rebro $\mathrm{z}$ odtisi prstov.

10. Odl. ostenja lonca; barva: zunaj: rdečerjava, znotraj svetlo rjava; površina: glajena; sestava: finozrnata; okras: stožčasta aplika in vodoravna niza vtisnjenih krožcev. Op.: datacija: eneolitik.

11. Odl. ustja in ostenja lonca barva: zunaj svetlo rdečerjava , znotraj sivorjava; površina: gladka; sestava: finozrnata.

12. Odl. ostenja lonca $z$ držajem; barva: zunaj svetlo sivorjava, znotraj rjavordeča; površina: gladka; sestava: finozrnata.

13. Odl. ostenja lonca; barva: zunaj temno sivorjava, znotraj rjavordeča; površina: gladka; sestava: drobnozrnata; okras: vodoravno plastično rebro z odtisi prstov.

14. Odl. ostenja lonca; barva: zunaj temno sivorjava; znotraj rjavordeča; površina: gladka; sestava: drobnozrnata; okras: vodoravno plastično rebro z odtisi prstov.

15. Odl. ustja in ostenja latvice; barva: zunaj sivorjava, znotraj temno sivorjava; površina: glajena; sestava: finozrnata.

ČOVIĆ, B. 1984, Praistorijsko rudarstvo i metalurgija u Bosni i Hercegovini (Das prähistorische Bergbauwesen und die Metalurgie in Bosnien un der Herzegowina). - Godišnjak 22, Centar za balkanološka ispitivanja 20, 111-144.

DRAKSLER, M. 2007, Območje Zagorja v prazgodovini (Das Gebiet von Zagorje ob Savi in der Vorgeschichte). - Arheološki vestnik 58, 121-155.

DULAR, J., S. CIGLENEČKI, A. DULAR 1995, Železnodobno naselje in zgodnjekrščanski stavbni kompleks na Kučarju pri Podzemlju / Eisenzeitliche Siedlung und frühchristlicher Gebäudekomplex auf dem Kučar bei Podzemelj. - Opera Instituti Archeologici Sloveniae 1.

GABROVEC, S. 1966, Zagorje v prazgodovini (Zagorje in der Vorgeschichte). - Arheološki vestnik 17, 19-50.

HELLMUTH, A. 2014, Butter, Wein oder Honig? Betrachtungen zu einer besonderen Gefässbodenform aus der Gradina von Monkodonja bei Rovinj in Istrien (Maslo, vino ali med? Razmislek o posebni obliki dna posod $\mathrm{z}$ Gradine Monkodonja pri Rovinju v Istri). - V: S. Tecco Hvala (ur.), Studia Praehistorica in Honorem Janez Dular, Opera Instituti Archaeologici Sloveniae 30, 65-79.

HORVAT, M. 1999, Keramika: tehnologija keramike, tipologija lončenine, keramični arhiv. - Ljubljana.
16. Odl. vratu in ostenja lonca; barva: zunaj svetlo rdečerjava, znotraj rdečerjava; površina: brisana; sestava: finozrnata; okras: vrezani šrafirani trikotniki in vodoravna linija.

17. Odl. ostenja lonca; barva: zunaj temno rdečerjava, znotraj svetlo siva; površina: gladka; sestava: drobnozrnata; okras: vodoravno plastično rebro $\mathrm{z}$ odtisi prstov.

18. Odl. ustja in ostenja latvice; barva: temno siva; površina: zunaj brisana, znotraj gladka; sestava: finozrnata.

19. Odl. ročaja; barva: svetlo rdečerjava; površina: glajena; sestava: finozrnata.

20. Bikonično vretence; barva: svetlo rdečerjava; površina: glajena; sestava: drobnozrnata.

21. Odl. ustja ciborija $\mathrm{z}$ vodoravnim rebrom na vratu; barva: zunaj sivorjava, znotraj svetlo rjava; površina: brisana; sestava: finozrnata.

22. Odl. ostenja in dna lonca $\mathrm{z}$ nogo; barva: zunaj temno siva, znotraj zelo svetlo rjava; površina: gladka; sestava: finozrnata.

23. Odl. ročaja pekve; barva: rdečerjava; površina: glajena; sestava: finozrnata.

24. Odl. svitka; barva: zunaj rdečerjava, znotraj sivorjava; površina: glajena; sestava: grobozrnata.

25. Odl. svitka; barva: svetlo rjava; površina: glajena; sestava: drobnozrnata.

26. Odl. dna lonca; barva: zunaj svetlo rdeča, znotraj sivorjava; površina: glajena; sestava: finozrnata.

27. Odl. dna lonca; barva: zunaj sivorjava, znotraj svetlo rdečerjava; površina: gladka; sestava: drobnozrnata.

28. Odl. svitka; barva: svetlo sivorjava; površina: brisana; sestava: drobnozrnata.

LAHARNAR, B. 2018, Kovinske in steklene najdbe ter kamniti kalupi iz železnodobne naselbine na Mostu na Soči / Metal finds, glass finds and stone moulds from the Iron Age settlement at Most na Soči. - V: J. Dular, S. Tecco Hvala (ur.), Železnodobno naselje Most na Soči. Razprave / The Iron Age settlement at Most na Soči. Treatises, Opera Instituti Archaeologici Sloveniae 34, 195-247.

OGRIN, M. 1998, Trortasta fibula v Sloveniji (Die Dreiknopffibel in Slowenien). - Arheološki vestnik 49, 101-132.

TECCO HVALA, S. 2012, Magdalenska gora. Družbena struktura in grobni rituali železnodobne skupnosti / Magdalenska gora. Social structure and burial rites of the Iron Age community. - Opera Instituti Archaeologici Sloveniae 26.

TECCO HVALA, S. 2014, Kačaste fibule z območja Slovenije / Serpentine fibulae from Slovenia. - Arheološki vestnik $65,123-186$.

TECCO HVALA, S. 2017, Grobovi iz mlajšega halštatskega obdobja na Molniku (Graves from the Late Hallstatt period at Molnik). - V: S. Tecco Hvala (ur.), Molnik pri Ljubljani v železni dobi / The Iron Age site at Molnik near Ljubljana, Opera Instituti Archaeologici Sloveniae 36, 109-118.

TERŽAN, B. 1976, Certoška fibula (Die Certosafibel). Arheološki vestnik 27(1977), 317-536. 


\section{New Early Iron Age finds from Zagorje ob Savi and Sava near Litija (Slovenia)}

\section{Summary}

Zagorje ob Savi is a town located in a narrow valley among the hills north of the River Sava and known as an archaeological site for more than a century. A cemetery from the Early Iron Age was unearthed there at the end of the $19^{\text {th }}$ century, at the Milačeva hiša site (Fig. 1:2) located at the foot of the Ocepkova gmajna hill, while further nine graves came to light during the preliminary archaeological investigations in July 2011, this time at the adjacent Cesta Borisa Kidriča site (Fig. 1: 1). The recent graves were found in three clusters. The first is composed of Graves 1, 2, 3 in the northwestern part of the excavation area, the second of Graves 4, 5, 6, 7 and 8 in the central part and the third of Grave 9 that is slightly removed from the rest in the south-eastern part (Fig. 2).

The grave pits were dug into an alluvial layer mixed with dolomite detritus that formed at the foot of the hill. Most had a stone lining. Skeletons in six of the graves were relatively well preserved (Figs. 4-7), in others almost completely destroyed. The graves differed in orientation, either parallel with or perpendicular to the slope, which is believed to be an adaptation to the inclined terrain. Grave goods and anthropological analysis have revealed the remains in Gr. 2, 3 and 9 as male, in Gr. 6 and 7 as children's and in Gr. 5 and 8 as female (see fn. 25).

Some of the graves were robbed. One of these is Gr. 1 in the first cluster, which revealed no goods. Graves 2 and 3 of men were also almost empty, though the considerable size of the grave pits suggests they must have held rich burials. Grave 2 contained a pair of Certosa fibulae of Type XII (Fig. 3; Pl. 1: 1,2), characteristic of the Negova horizon in the Dolenjska Hallstatt group; their special feature is the inlaid corals on the foot knob. Grave 3 only contained four bronze buttons (Pl. 1: $3-6)$, one of them with an indented head that has close parallels from Molnik near Ljubljana, found in a grave of a man buried in the Negova horizon.

Grave 4 of the central cluster was also robbed. Female Grave 5 only held a jar (Fig. 4; Pl. 1: 9). In Grave 6, pieces of bent bronze wire were found on top of the poorly preserved skeleton of a child (Fig.
5; Pl. 1: 10). Grave 7 also contained the remains of a child, found with a bronze bracelet on the arm and a bone bead in the neck (Pl. 1: 7,8). The best surviving skeleton was that of an adult woman in Gr. 8; she was found with a bronze hair ring of flat wire with a longitudinal groove, a serpentine fibula with a disc-guard, amber beads forming a necklace and a jar (Fig. 6; Pl. 2: 1-4). The fibula, hair ring and necklace are all items typical of the female costume of the $6^{\text {th }}$ century $\mathrm{BC}$ in the Dolenjska region.

Grave 9 of an adult man in the south-eastern part of the excavation area was located closest to the graves unearthed at Milačeva hiša in 1894-1896 (Fig. 1: 2). He was buried with a belt (Fig. 7; Pl. 1: 11-15), such as forms part of the Dolenjska male costume typical of the Certosa horizon. The stray find of an iron spearhead, recovered in the vicinity of this grave ( $P l .2: 9)$, may originally also have belonged among its grave goods. Chronologically, this burial corresponds with the group of burials at Milačeva hiša that include a rich grave of a man buried with a figurally decorated belt plate and situla, a standard set of weapons (two spears, battle axes) and a horse with Scythian horse gear.

The excavations at the Cesta Borisa Kidriča site (Fig. 1: 1) have shown that burial began here in the Serpentine horizon and continued in the Negova horizon. Attributable to the latter are the graves of the first cluster, located beside a rocky face that represented the edge of grounds suitable for burial. It is possible that this limitation led to burials at another location - on the opposite foot of the hill of Ocepkov hrib, in the area of the modern street of Levstikova ulica (Fig. 1: 3), where artefacts came to light that originate from two La Tène graves.

Apart from the burials, excavations at the same site also revealed terraces along the length of the excavation area (Fig. 8). They were gradually covered over by colluvial deposits that contained numerous pottery sherds and other pieces dating to the Late Bronze and Early Iron Ages, but not in a continuous span. These finds, brought down the slope of Ocepkov hrib (Fig. 1: 4) by erosion, 
might originate from the settlement that presumably existed on its top, but has never been investigated. The narrow width of the excavation area and extensive destruction of the archaeological remains here offered little insight into the stratigraphy of the site, making it very difficult to interpret the few and heavily damaged remains.

Northwest of the second cluster of burials (Fig. 2), a line of stones (Structure 1) was unearthed that may represent the remains of building foundations or terrace reinforcement. A bronze threeknobbed fibula or Dreiknopffibel (Pl. 2: 5) was found here, but it may have originated from one of the destroyed graves; it is an item worn in the Dolenjska Hallstatt group in the Certosa horizon.

The area of the first cluster of graves revealed a heap of stones (Structure 2) (Fig. 9), which was cut by the pit of Grave 2. This spot yielded a substantial quantity of ceramic finds (Pls. 3: 10-15; 4: 1-6), iron slag, house daub and animal bones that indicate habitations, possibly the remains of dwellings on the terrace.

The line of stones that may be the remains of building foundations and the cultural layers with habitation finds ( $P l .4$ ) suggest that a settlement existed here first, followed by a cemetery. The ceramic finds are attributable to two or more phases, to the Late Bronze and Early Iron Age. The quantity of iron slag furthermore indicates that iron ore processing took place in the vicinity.

Archaeological remains also came to light above Sava near Litija (Fig. 10), west of Zagorje ob Savi, a site previously unknown to archaeologists. During construction works, a bronze fibula and an iron spearhead (Fig. 11) were found by chance at the south-eastern edge of the low elongated hill of Vinarica, stretching from southeast to northwest along the left bank of the River Sava. The construction work had already concluded before archaeologists could gain more precise data on the archaeological context.

The two items are most likely grave goods and indicate the existence of a cemetery. The bronze fibula with double kettledrums (Doppelpaukenfibel) decorated with incisions (Fig. 11:2) is a variant of the Alpine Blech-paukenfibeln, dated to the second half of the $5^{\text {th }}$ century BC in Dolenjska and Posočje. The closest parallels for the spearhead (Fig. 11: 1) come from Dolenjska, where slender spearheads with a short blade and long socket appear in the last phase of the Hallstatt period. The contemporaneity of the two artefacts suggest they might even have formed part of the same grave group from the Negova horizon ( $5^{\text {th }}$ century BC).

The burials from Zagorje ob Savi and the chance finds from Sava near Litija offer new evidence on the flat inhumation cemeteries that came to dominate the region of Posavsko hribovje towards the end of the Hallstatt period. The goods recovered in this region, lying north of the River Sava, show the characteristics of the Dolenjska cultural group, while the disposition of the graves differs from the standard tumuli of Dolenjska. Flat inhumation cemeteries dominate the entire valley of the River Medija, which was intensively settled only in the Late Hallstatt period. The presumed cemetery in Sava near Litija adds another site to the archaeological map of the area.

Translation: Andreja Maver
Miha Murko
ZVKDS
Poljanska cesta 40
SI-1000 Ljubljana
miha.murko@gmail.com
Matej Draksler
Skupina STIK
Cesta Andreja Bitenca 68
SI-1000 Ljubljana
draksler.matej@gmail.com
https://orcid.org/0000-0001-5795-9050

Slikovno gradivo: Sl. 2 (Matej Strašek, Stane Hafner). - Sl. $3 b$ (foto: Tomaž Lauko, NMS). - Sl. 5 (foto: Matija Lukić). Sl. 11 in T. 1-4 (Matevž Lavrinc). 


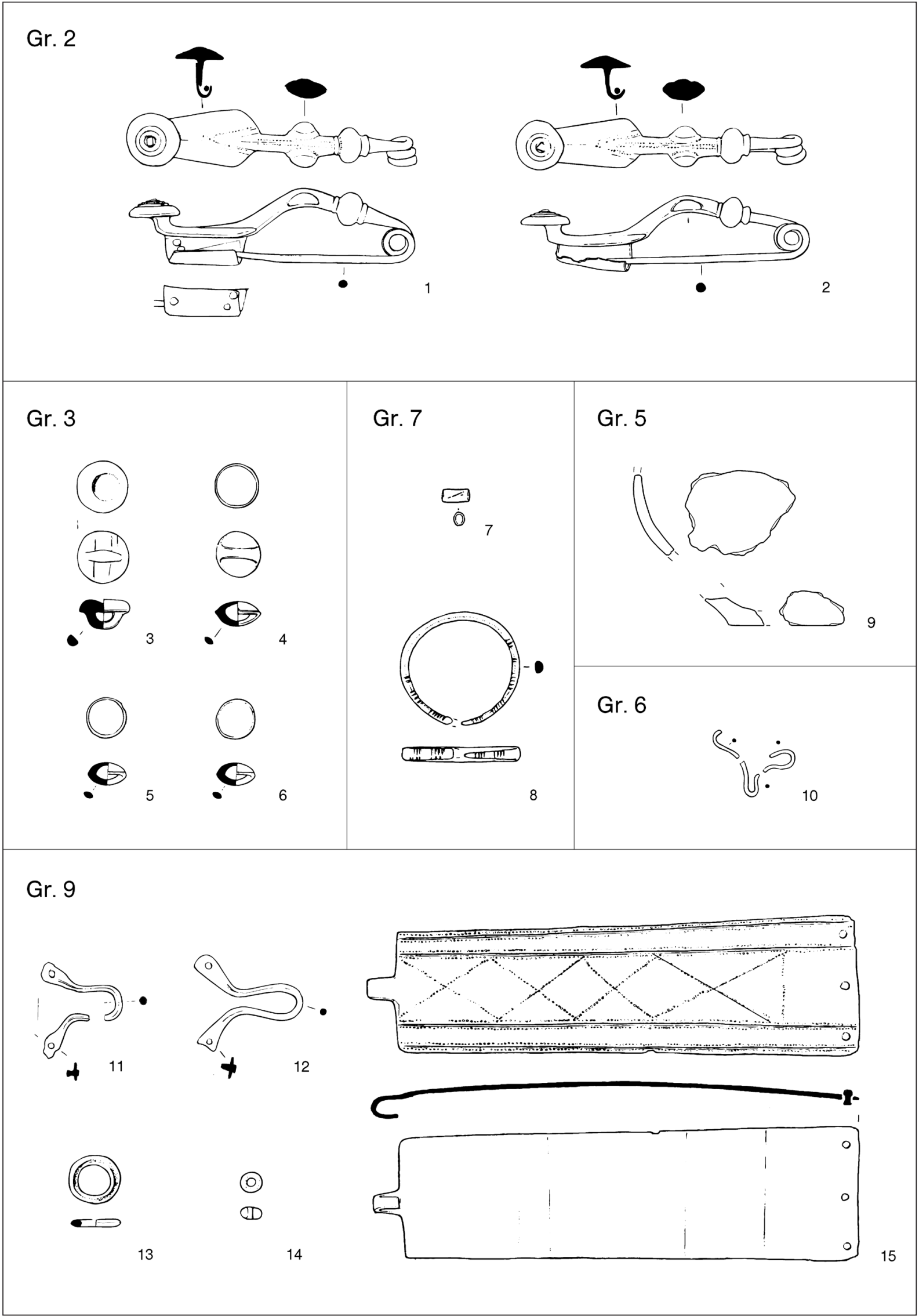

T. 1: Zagorje ob Savi - Cesta B. Kidriča. Grob 2. 1-6,8,10-13,15 bron; 7,14 kost; 9 keramika. M. $9=1: 4$; ostalo = 1:2. Pl. 1: Zagorje ob Savi - Cesta B. Kidriča. Grave 2. 1-6,8,10-13,15 bronze; 7,14 bone; 9 pottery. Scale $9=1: 4 ;$ other $=1: 2$. 
Gr. 8
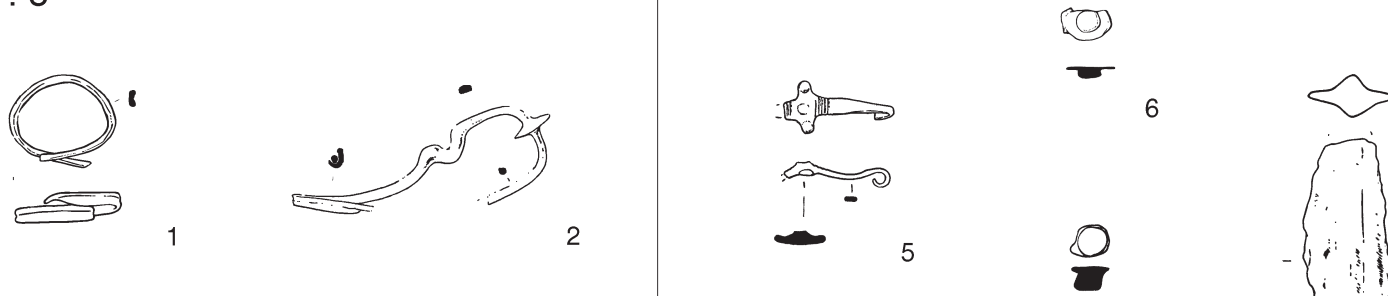

- (-) 0 b

(1) D O $\mathbb{D} 0$

\section{3}

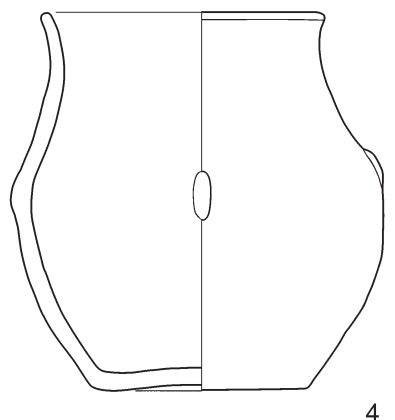

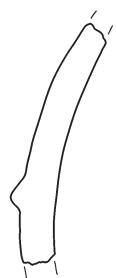

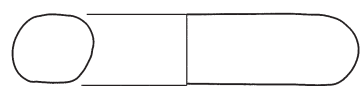

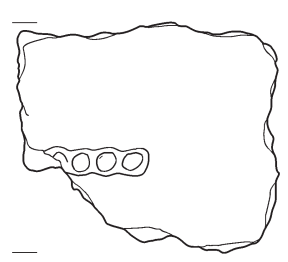

12

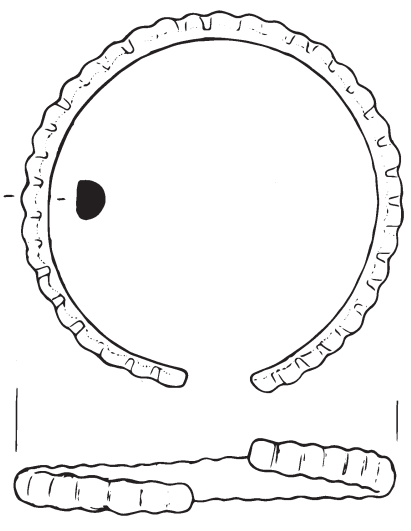

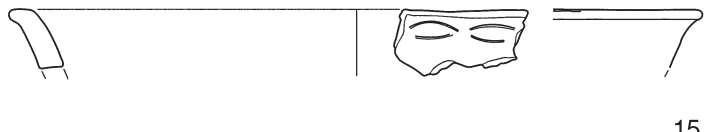

15

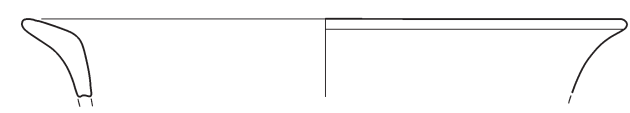

16
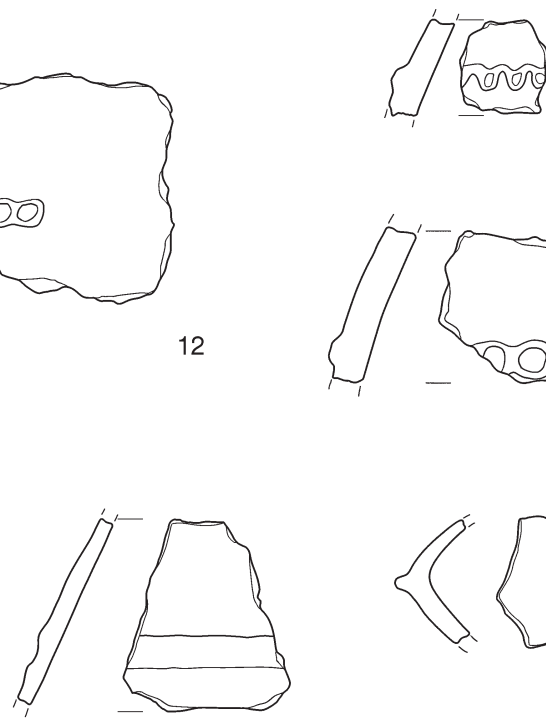

13

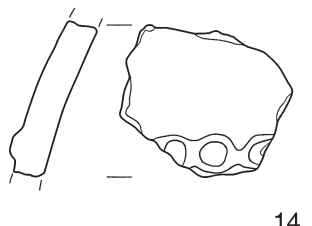

14

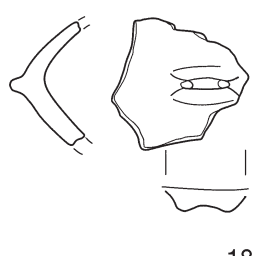

17
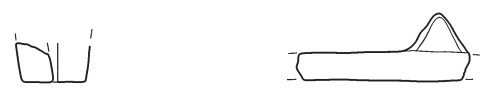

20

T. 2: Zagorje ob Savi - Cesta B. Kidriča. Grob 8 (1-4); sporadične najdbe (5-9); zasutje gr. 1 (10-16); zasutje gr. 2 (17); zasutje gr. 5 (18); zasutje gr. 9 (19,20). 1,2,5-8 bron; 3 jantar; 9 železo; ostalo keramika. M. 1-3,5-8 = 1:2; ostalo 1:4. Pl. 2: Zagorje ob Savi - Cesta B. Kidriča. Grave 8 (1-4); stray finds (5-9); fill of Gr. 1 (10-16); fill of Gr. 2 (17); fill of Gr. 5 (18); fill of Gr. 9 (19,20). 1,2,5-8 bronze; 3 amber; 9 iron; other pottery. Scale 1-3,5-8 = 1:2, other 1:4. 


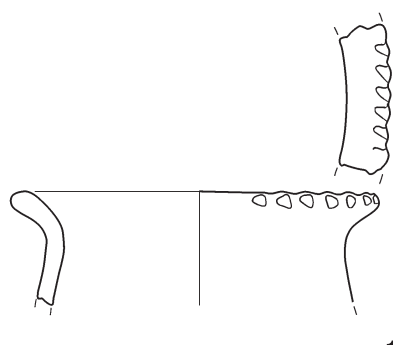

1

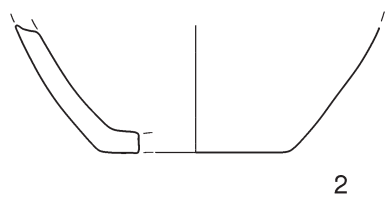

2

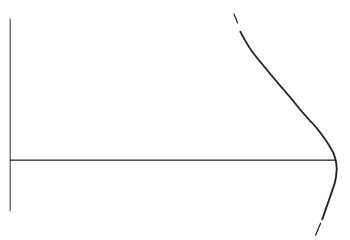

6
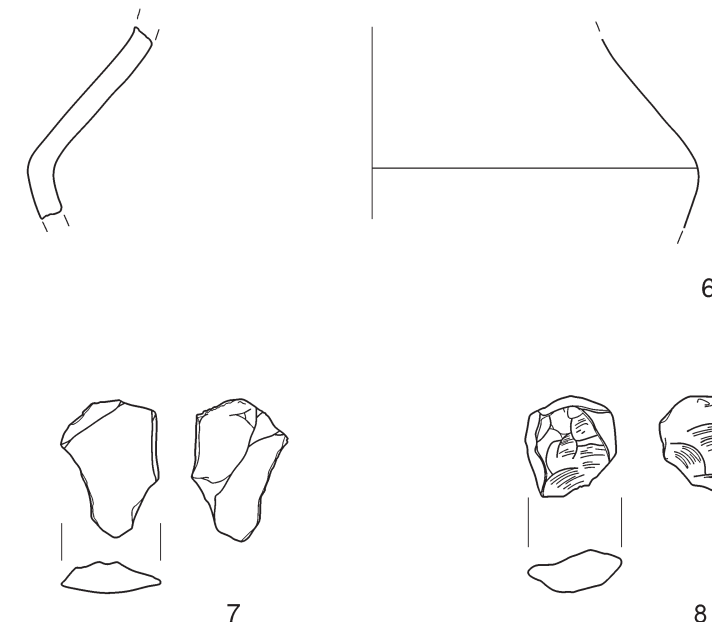

7

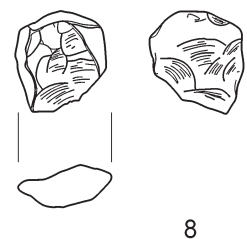

8
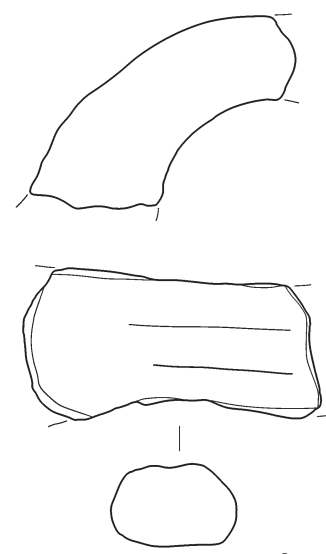

3
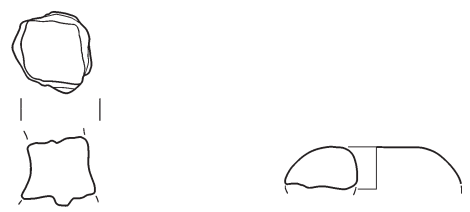

5

4

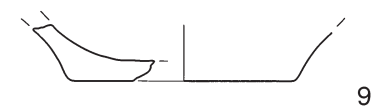

9
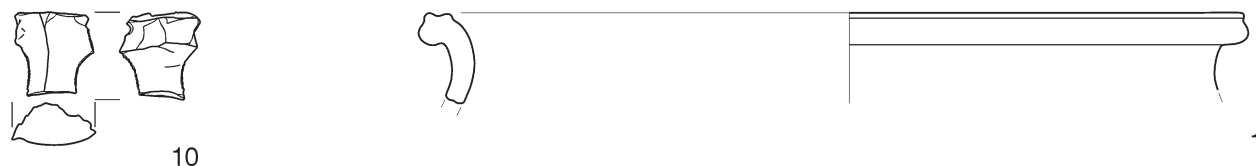

10

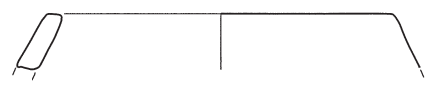

12

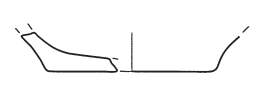

13
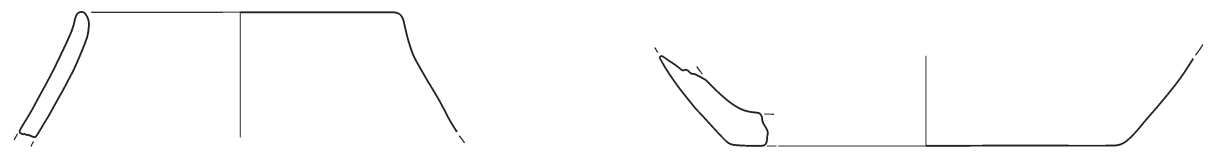

T. 3: Zagorje ob Savi - Cesta B. Kidriča. Zasutje groba 3 (1-5); zasutje gr. 4 (6-9); kamnita groblja 2 (10-15). 7,8,10 kamen; ostalo keramika. M. 7,8,10 =1:2; ostalo $=1: 4$.

Pl. 3: Zagorje ob Savi - Cesta B. Kidriča. Fill of Grave 3 (1-5); fill of Gr. 4 (6-9); Structure 2 (10-15). 7,8,10 stone; other ceramics. Scale $7,8,10=1: 2$; other $=1: 4$. 


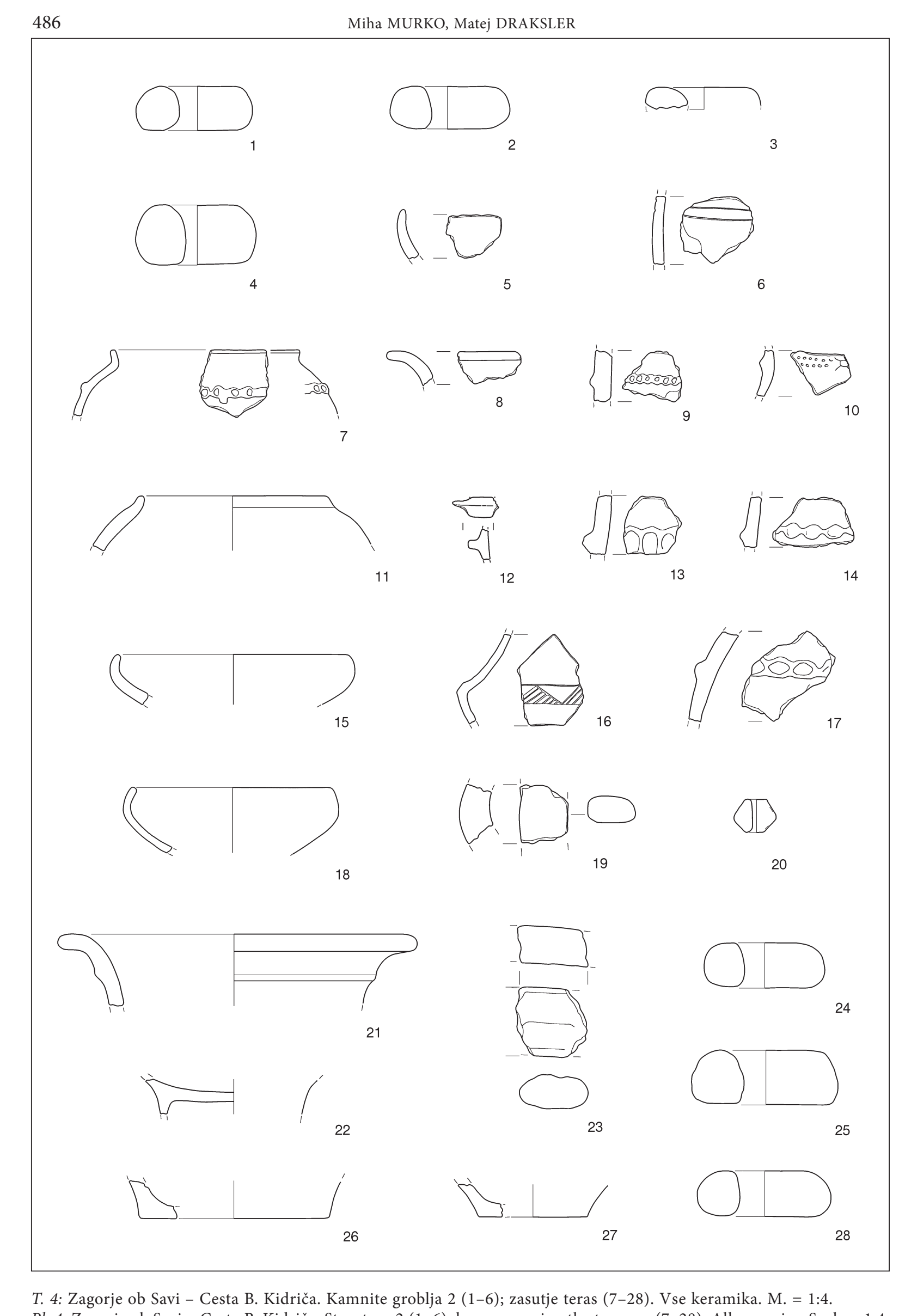

